\title{
The Role of the Formal Knowledge in the Formation of the Proof Image: A Case Study in the Context of the Infinite Sets *
}

\author{
Ozan Pala ${ }^{a}$ and Serkan Narlı

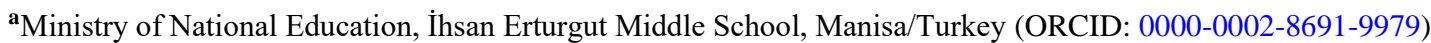 \\ ${ }^{\mathbf{b}}$ Dokuz Eylül University, Buca Faculty of Education, Izmir/Turkey (ORCID: 0000-0001-8629-8722)
}

Article History: Received: 11 March 2020; Accepted: 27 August 2020; Published online: 23 September 2020

\begin{abstract}
Although the emphases on the importance of proving in mathematics education literature, many studies show that undergraduates have difficulty in this regard. Having researchers discussed these difficulties in detail; many frameworks have been presented evaluating the proof from different perspectives. Being one of them the proof image, which takes into account both cognitive and affective factors in proving, was presented by Kidron and Dreyfus (2014) in the context of the theoretical framework of "abstraction in context". However, since the authors have not deepened the relationship between the proof image and formal knowledge, this article was intended to fill this gap. In this study, which is part of a larger doctoral thesis, descriptive method one of the qualitative methods was used. The participants of the study were three pre-service teachers selected via criterion sampling method among sophomore elementary school mathematics teacher candidates. In parallel with a course relating to Cantorian Set Theory, task-based individual interviews (Task I-II-III-IV) were conducted in the context of the equivalence of infinite sets. The subject of "infinity" had been chosen as the context of the study since it contains a process that goes from intuitive to formal. In the first task (Task I), the actions that the participants had performed without enough pre-knowledge was examined in terms of the proof image. In the second task (Task II) carried out after a course, in which basic knowledge was presented, the same question was asked to the participants again. Thus, the processes formed with the presence of formal knowledge were analysed. As a result of the descriptive analysis executed on the data of both tasks, it was determined that $C$, who was one of the participants, reached a proof image in the second task although she failed in the first task. Therefore, in this study, findings of her proving activity were shared. Consequently, formal knowledge has been identified to be directly related to each of the components of the proof image and, its main contributions have been listed as headings.
\end{abstract}

Keywords: Proof image, infinity, Cantorian set theory, proof, mathematics education

DOI:10.16949/turkbilmat.702540

\begin{abstract}
Öz: Matematik eğitimi çalışmalarında ispatlamanın önemine sıklıkla vurgu yapılmasına rağmen araştırmalar üniversite öğrencilerinin bu konuda güçlük çektiğini göstermektedir. İspat sürecinde yaşanan bu güçlüklerin araştırmacılar tarafindan ayrıntılı olarak ele alınması sayesinde ispatı farklı perspektiflerden değerlendiren birçok görüş sunulmuştur. Bunlardan biri olan ve ispat sürecinde hem bilişsel hem duyuşsal faktörleri dikkate alan ispat imajı, Kidron ve Dreyfus (2014) tarafindan "bağlamda soyutlama" teorik çerçevesi bağlamında sunulmuştur. Ancak, ispat imaj1 ile formal bilgi arasındaki bağlantı yazarlar tarafından derinleştirilmediğinden, bu makalede bu boşluğun doldurulması amaçlanmıştır. Daha geniş bir doktora tez çalışmasının parçası olan bu çalışma, betimsel türde nitel bir araştırmadır. Çalışmanın katılımcıları ilköğretim matematik öğretmenliği ikinci sınıf öğrencileri arasından ölçüt örnekleme yöntemi ile seçilen üç öğretmen adayıdır. Bu katılımcıların, Cantor Küme Teorisi bağlamında aldıkları bir derse paralel olarak sonsuz kümelerin denkliğine dair etkinlik temelli bireysel mülakatlar (Uygulama I-II-III-IV) gerçekleştirilmiştir. Sonsuzluk konusu, ispat imajının doğasına uygun olarak sezgiselden formele giden bir çerçeveyi barındırdığından çalışmanın bağlamı olarak tercih edilmiştir. İlk çalışmada (Uygulama I) katılımcıların yeterli ön bilgiye sahip olmadıkları durumda gerçekleştirecekleri eylemlerin ispat imajı açısından incelenmesi sağlanmıştır. Temel bilgilerin sunulduğu bir dersin ardından gerçekleştirilen ikinci çalışmada (Uygulama II) katılımcılara aynı soru tekrar yöneltilmiş ve böylece onların formal bilgiye sahipken oluşturdukları süreçlerin incelenmesi sağlanmıştır. Her iki uygulamanın verileri üzerinde yapılan betimsel analizler sonucunda katılımcılardan Ç’nin ilk uygulamada bir ispat imajına sahip olmamasına rağmen ikinci uygulamada sahip olduğu belirlenmiştir. Bu nedenle bu çalışmada onun ispat süreçlerine dair bulgular paylaşılmıştır. Sonuç olarak formal bilginin, ispat imajının oluşumuna olanak veren bileşenlerin her biri ile doğrudan bağlantılı olduğu belirlenmiş ve temel katkıları başlıklar halinde sıralanmıştır.
\end{abstract}

Anahtar Kelimeler: İspat imaj1, sonsuzluk, Cantor küme teorisi, ispat, matematik eğitimi

Türkçe sürüm için tıklayınız

\section{Introduction}

Individuals who involved in the learning process often need to reveal the correctness or incorrectness of a proposition they encounter. This issue related to the justification of knowledge can be associated with the proof

Corresponding Author: Ozan Pala (D)

email: ozanpala@yahoo.com

* This paper was produced from the doctoral dissertation, which carried out within the scope of Dokuz Eylül University Institute of Educational Sciences, of the first author. This dissertation study is also supported by both TUBITAK BİDEB 2211 program and Dokuz Eylül University Scientific Research Projects Coordination Unit.

Citation Information: Pala, O. \& Narl1, S. (2020). The role of the formal knowledge in the formation of the proof image: A case study in the context of the infinite sets. Turkish Journal of Computer and Mathematics Education, 11(3), 584-613. 
dimension of mathematical thinking. Proof is one of the key components of mathematics (Thompson, Senk \& Jhonson, 2009) and is a time-consuming subject in mathematics teaching. Because, thanks to the proofs, it is possible to reorganize the mathematical knowledge (Herbst, 2002). In addition to this, it can be said that various opinions concerning the concept of proof have emerged in the mathematics education literature, and different definitions, which highlight different dimensions of the proof, were presented. In the most general sense, the path followed by the generalization of mathematical knowledge can be called "proof" (Altun, 2005). Besides, Stylianides (2007) emphasizing the "explanation" function of the proof, defines this process as a series of interrelated arguments put forward to verify or falsify a claim. On the other hand, Harel and Sowder (1998) stated that this process was carried out on the purpose of annihilating doubts about the "accuracy" of the observations. Moreover, as stated by Tall (1998), the main function of mathematical proof is to show that claims reach a conclusion thanks to the logical steps. Thanks to this skill, which can be evaluated as the essence of mathematical activity, not only the new mathematical knowledge can be discovered, but also the other existing mathematical knowledge can be developed. Therefore, for Almeida (2000), proof is a basic activity that ensures the guarantee of mathematical knowledge. Besides, the fact that proof is a tool for learning mathematics (Knuth, 2002) can be seen as an important reason why this skill is frequently emphasized especially by mathematics educators. Thanks to proof, the underlying relationships (true or false) of a claim can be "causally" explained (Hanna, 2000), and this can be interpreted as an important dimension of the "pedagogical" function of the proof.

The proving activities, which have great importance at all levels of teaching, play a significant role in the learning and teaching of many mathematical subjects, especially at the university level. The proving ability in advanced mathematical topics is considered one of the critical abilities (Weber, 2001) and the development of this ability is among the objectives of many courses. In the meantime, although the importance of proof in mathematics education studies is frequently emphasized, researches show that undergraduates have difficulty in this regard. One of the reasons for these difficulties is insufficient understanding of the nature of the proof. For example; Sarı, Altun and Aşkar (2007) determined that individuals have developed an incomplete understanding of the proof, by sticking to reasons based on empirical results. Selden and Selden (1995) also stated that undergraduates adhere to their informal approach in their proof process. On the other hand, Attwood (2001) emphasized the deficiencies experienced in organization and argumentation in his thesis study. Similar epistemological-based challenges are also encountered in the work of other researchers (e.g., Almeida, 2000; Baker \& Campbell, 2004; Harel \& Sowder, 2007; Knapp, 2005). Besides, it can be thought that a significant part of the difficulties related to the proving is due to the pedagogical or psychological factors including readiness (pre-knowledge, language \& representation, reasoning skills, etc.) in particular. At this point, when the mathematics education literature is investigated, it can be seen that various findings regarding the failures arising from individual factors such as "readiness", "misconceptions" and "metacognition" are emphasized by many researchers (e.g., Antonini \& Mariotti, 2007; Doruk \& Kaplan, 2017; Güler, Özdemir, \& Dikici, 2012; Harel \& Sowder, 2007; Jones, 2000; Knapp, 2005; Ko \& Knuth, 2009; Pala \& Narl1, 2018a; Weber, 2006). For example, Jones (2000) stated that undergraduates could not adequately internalize the representations and presentations required to create proof, while Knapp (2005) emphasized the difficulties of students at this level in formal understanding of mathematics. On the other hand, Antonini and Mariotti (2007) highlighted methodological deficiencies. Another important deficiency in the proof activities is the inadequacies based on the "intuitive understanding" that accompanies this process (Moore, 1994). Intuitive structures underlying many theories that try to explain the proof process are one of the primary elements for active understanding and productive thinking (Fischbein, 1982). Furthermore, as stated by Weber and Alcock (2004), intuitive reasoning is expected to be used as a complement to formal thinking in justification activities. Both explanatory and convincing proofs (called as semantic proof) can be created thanks to the intuitive processes guiding formal processes. Otherwise, it can be said that the "persuasion" dimension of proof cannot be fully revealed when the intuitive understanding is not arised.

Thanks to the detailed examinations related to difficulties experiencing in the proving process, which listed in general terms above, many different perspectives evaluating this process have been presented. For example, while Harel and Sowder (1998), who thoroughly examined the "justifications" of individuals in the proving, presented the proof schemes, Tall (1998) focusing on the "use of language" in this process, proposed a representation-based classification. Additionally, Weber (2001), who observed the case that students may fail to create proof even though they both know and apply the concepts, definitions, and theorems, defined the concept of strategical knowledge and emphasized its role. On the other hand, it can be also seen that other researchers (e.g., Güler \& Dikici, 2014; Hart, 1994; Harel \& Sowder, 1998; Weber \& Alcock, 2004) mostly focus on the cognitive dimension of the proof and its cognitive products. At this point, considering the fact that proving is also a learning activity, it can be thought that this process can be interpreted from the "knowledge construction" perspective. However, when the literature is examined, it can be concluded that there is an insufficient number of proof studies based on the knowledge construction process. Thanks to such studies, it may be possible to provide a multi-dimensional perspective by combining the cognitive factors involved in the process with affective 
factors. Besides, it can be determined how each stage of the proving process is structured by individuals, and the underlying causes of the difficulties, which experienced in this process, can be interpreted better.

\subsection{Theoretical Framework}

Mathematics independent of proof skill cannot be considered (Schoenfeld, 1994), and in the same way, all students cannot be expected to go through the same processes in proof activities (Weber \& Alcock, 2004). Learners are expected to demonstrate their own unique experiences, as their knowledge and pre-experiences are different. Besides, it can be stated that the various elements (such as readiness, strategic information, intuitive understanding) that form a basis for the proving activities are also part of the concept image in the mind of the individual. Because it is important to have a rich image to use the concepts flexibly. Therefore, in order to be successful in proof activities, the individual is expected to have many things such as situations, facts, features, relationships, shapes, and visuals related to the concept in question (Selden \& Selden, 2007). Having a rich concept image, on the other hand, is possible with the correct structuring of the knowledge construction process. Hershkowitz, Schwarz and Dreyfus (2001), who examined this process with socio-cultural dimensions, presented the RBC abstraction theory in the context of the Abstraction in Context (AiC) framework to analyze knowledge construction at the micro-analytical level. In this context, it can be said that construction of a new knowledge is possible thanks to the epistemic actions of "Recognizing (R-)", "Building With- (B-)" and, "Construction (C-)" respectively. Recognizing ( $\mathrm{R}-$ ), which is the first step of the abstraction process, is recognition of a pre-formed structure by the individual in the problem solving process (Türnüklü \& Özcan, 2014). On the other hand, the use of a pre-formed mathematical structure to solve the problem is explained by Building With- (B-) action (Schwarz, Dreyfus, Hadas \& Hershkowitz, 2004). Construction (C-), which is the last stage of the process, refers to the restructuring of previous mathematical structures through partial change (Bikner-Ahsbahs, 2004). The "restructuring" mentioned here refers to a vertical mathematization process. Therefore, thanks to the Construction (C-) action, it is possible to discover a "new" mathematical structure that was previously unavailable for the individual (Hershkowitz, Schwarz \& Dreyfus, 2001). On the other hand, contrary to unpredictable coincidences, it can be said that some of the basic mechanisms involved in the mathematical thinking process play significant roles during this discovery (Liljedahl, 2004). "Aha! Experience" and "Enlightenment" are among these mechanisms that accompany the knowledge construction process. Thanks to the "Aha! Experience", which can be imagined as a spark of electricity that suddenly shines, it can be said that the knowledge structures already exist in the learner's mind come together with a suitable combination and, in this way, an original idea is allowed to emerge suddenly and definitely (Liljedahl, 2005). Besides, thanks to this new knowledge, it can be said that the individual can better understand the situation, which he or she involved in, and is "Enlightened" in the sense of Rota (1997). The concept of enlightenment, which can be defined as providing an insight into the connections underlying the statement to be justified, is beyond the validation of the formal reality of a mathematical concept. It can be thought of as understanding the role of a "concept" in the context of other mathematical knowledge structures. In other words, it can be interpreted that a mathematical expression is enlightening to the extent of the meaningfulness of the whole, which it forms with other structures. Considering the complex relationship network in the proving process, it can be concluded that the formation process of a mathematical concept is closely related to both the "Aha! Experience", which led to the discovery of new knowledge, and the "Enlightenment", which following it (Kidron \& Dreyfus, 2010).

By considering the conceptual framework presented up to this stage, Kidron and Dreyfus (2014), who examined both the interaction between intuitional and logical thinking in the proving process and the knowledge constructing resulting from this interaction with the theoretical framework of Abstraction in Context, have reached the concept of the proof image as a result of micro-analytical analysis of the proof processes of two professional mathematicians (named as $\mathrm{K}$ and $\mathrm{L}$ ). They introduced the concept of the proof image, which they define as an important step in the proving process, by comparing it with various perspectives on proof such as intuition (Fichbein, 1994), conceptual insight (Sandefur, Mason, Stylianides \& Watson, 2013), semantic proof production (Weber \& Alcock, 2009), concept image (Tall \& Vinner, 1981), and they formed proof image-formal proof analogy using the double-strand concept image-concept definition structure. Evaluating the experiences they have gained from other studies (Kidron \& Dreyfus, 2009, 2010), the authors explained the nature of the proof image as follows:

...the complementary nature of intuitive representations and logical thinking allows for an early stage of synthesis between the intuitive and the formal aspects of mathematics in the sense of Fischbein (1994). The notion of proof image nicely suits the beginning of such a synthesis because it consists of a mixture of selected previous constructs and logical links, both of which may be intuitive (Kidron \& Dreyfus, 2014, p. 229).

Accordingly, the authors stated that an individual, who attempted to understand why a claim is true, may have a proof image as long as he or she has the two components (Cognitive Understanding and Intuitive Conviction) together. These main components that constitute the proof image and their sub-dimensions are presented in Table 1 below: 
Table 1. Components of the Proof Image

\section{PROOF IMAGE (Kidron \& Dreyfus, 2014)}

\begin{tabular}{l} 
Cognitive Understanding \\
This component is the cognitive dimension that includes the \\
following sub-components based on selected (R-) previous \\
constructs to demonstrate the accuracy of any claim, and the \\
cognitive intuition connecting them. \\
\hline$C_{1}-$ Being Personal \\
The image that comprising traces of the individual's \\
inferences and experiences, and develops by feeding \\
on them. \\
Handling of the selected mathematical structures in a \\
connected frame with logical links instead of an \\
isolated form. \\
The image progress from a simple form to a complex \\
form, and also its former forms are encapsulated by the \\
later ones. \\
\hline$C_{3}-$ Being Dynamic \\
The holistic development of the image allows a \\
formation.
\end{tabular}

\section{Intuitive Conviction}

The affective dimension that provides an intuitive conviction for the actions performed by the individual in the proving process, and is intricately linked to cognitive understanding.

It includes cognitive intuition and logic that enrich the understanding of the individual.

\subsection{Problem Statement}

The authors, who presented the theoretical framework of the proof image, defined the components of the image in the context of a theoretical basis in their original work and shared examples of them in two proving activities. On the other hand, a case where the proof image does not exist has not been examined and, the connection between the proof image and the formal proof has not been deepened. By considering this gap in the theoretical framework, the problem of this study was determined as "What is the effect of the formal knowledge on the formation of the proof image when examined in the context of the infinite sets?". The context of the study was chosen as Cantorian Set Theory and the equivalence relationships between infinite sets, which are dealt with in this context. Because, just like Kidron and Dreyfus's (2014) explanations on the development of the proof image, many studies in the literature (e.g., Kolar \& Čadež, 2012; Pala \& Narl1, 2018a, 2018b; Tsamir, 1999) emphasize that the concept of infinity includes an increasingly complex intellectual process proceeding from intuitive to formal. Considering this similarity between developmental processes, it can be said that the concept of "infinity" can provide an appropriate context to examine the proof image. Besides, it is especially thought that the contribution of the formal knowledge in the formation of the proof image can be determined through activities in which sufficient knowledge exists and not. In this way, suggestions for instructional applications can be presented, in particular, by clarifying the difference between situations with and without the proof image. Because, as Selden and Selden (2007) stated, even being aware of the difficulties related to proof and proving can make educators more sensitive about how to help students.

\section{Method}

In this section, information about the design, the participants, process, data collection tools, and data analysis techniques of the study are presented.

\subsection{Research Design}

This study, which is a part of a larger doctoral thesis study, is a descriptive type of qualitative research. Qualitative research can be defined as "Research in which qualitative data collection techniques such as observation, interview, and document analysis are used and a qualitative process is followed to reveal perceptions and events in realistically and holistically in their natural environment (Yıldırım \& Şimşek, 2013, p. 39)". Besides, in descriptive research, events, objects, and concepts are explained by being described, and thus the relationships between the variables are revealed (Kaptan, 1998). Due to the in-depth and multidimensional examination of the proving processes in the research, case study design, which is one of the qualitative analysis methods, has been preferred. In this approach, factors related to one or more situations are investigated with a holistic approach, and in-depth analyses are carried out to determine "how they affect the situation" and "how they are affected by the situation" (Yıldırım \& Şimşek, 2013). According to Sönmez and Alacapınar (2011), it is a case study to examine a complex, special, and interesting phenomenon within its own conditions. In this method, an unknown fact can be discovered or a situation can be defined in detail. 


\subsection{Study Group}

The study group of the research consists of 3 sophomore pre-service mathematics teachers, who are selected by the criterion sampling method. This class level has been preferred as it contains intensive knowledge of Cantorian Set Theory and especially cardinality. Since the study aims to examine a situation in multiple dimensions and in-depth, the number of participants has been limited. Criterion sampling has been preferred as it allows the selection of pre-service teachers who have the qualifications determined concerning the problem. The main understanding of this sampling method is studying all situations that meet a set of pre-defined criteria. At this point, the criteria list determined for the participants who included in the study is presented below:

- Not having difficulty in expressing thoughts verbally or non-verbally

- Academic success in "Abstract Mathematics" course

- Volunteering to participate in the research

Since the framework of the proof image is based on the idea of socio-cultural abstraction, it has been taken into consideration that the participants must have sufficient communication skills for conveying their thoughts to others by organizing them. Individuals, who can use verbal and non-verbal language effectively, have been determined thanks to the 5-week in-class observations. In addition, participants were expected to have enough background as to the Abstract Mathematics course, which includes basic subjects such as symbolic logic, sets, relations, and functions, to perform the proofs expected to them. Because the Set Theory put forward by Georg Cantor includes concepts such as cardinality, infinite sets, and countability. At this point, their academic success in the previous year ( $1^{\text {st }}$ grade) has been taken into consideration. Finally, participants of the study have been selected among the individuals, who met the first two criteria and volunteered, in line with the expert opinion. These teacher candidates have been named as Ç, F and N. Participants completed the Basis of Mathematics and Abstract Mathematics courses from the proof-based courses at the $1^{\text {st }}$ grade level before the study and continued to take the Logic I and Linear Algebra I courses during the time of the study.

\subsection{Process, Data Collection and Analysis}

Before starting the study, the necessary ethical permissions have been obtained from the ethics committee of the relevant university institute. Then the data collection process started. The triangulation technique was used in the process. According to Büyüköztürk, Kılıç-Çakmak, Akgün, Karadeniz and Demirel (2013) triangulation is an application that allows two or more methods, which are integrated, to be used in research together instead of a single method and aims to enrich the method in this way. Following the determination of the participants, taskbased interviews (Task I-II-III and IV) were started to determine the ways of thinking and formal/ intuitive approaches regarding the equivalence of infinite sets. During the process, except for the pilot study, a total of 13 proof activities (4-times with each participant individually and, 1-time group study in a socio-cultural interaction environment) were executed. In addition, since this study focuses on the role of formal knowledge in forming the proof image, the shared data is limited to the first two tasks (Task I and Task II). In both tasks, teacher candidates were asked the following question and were expected to prove it:

"Are the entire infinite sets equivalent? If you think this is not true, please give two infinite sets example that you think they are not equivalent. "'

This question was selected (in line with the opinions of two experts) since it both contains the basic relations of the concept of cardinality in a multidimensional manner and allows the participants to use their intuitive approaches. As the proof questions addressed in task-based interviews include high-level cognitive skills and has long answers, the number of questions was limited. Tasks were carried out in parallel with the course of Logic 1, which includes topics related to Cantorian Set Theory, and they were scheduled at certain time intervals accordingly. Except for the first task, the pre-knowledge that participants needed were presented by the lecturer in the courses. As the proofs that participants would shape in situations, where they have insufficient preknowledge, were focused on, no pre-knowledge was presented before the first task. In addition, the participants did not encounter any of the questions, which were presented to them in the tasks, before. Right after the first task, the first course about the basic philosophy of Cantorian Set Theory was presented. In this course, it was provided that they acquired basic information about the concept of cardinality and it was exemplified by explaining that the equivalence of two infinite sets can be shown in line with the following definition:

$$
A \sim B \Leftrightarrow\{f \mid f: A \rightarrow B, \text { bijective }\} \neq \varnothing \text { (Güney \& Özkoç, 2015, p. 418) }
$$

Right after this phase (the day after the first task), the participants were asked the same question and expected to prove it. The second task aimed to compare the information structures / proof images and proof approaches the participants had before and after they received formal information. There were no restrictions with respect to their responses in order to ensure the participants' freedom of response. At each stage, the participants were asked to explain their proof processes out loud. The entire process was recorded by using two cameras and two different angles. While one of the cameras focused on the participants' answer sheets, the other one focused on 
their faces in order to analyze their feelings and intuitions. After the participants completed each proof process, semi-structured interviews were conducted with the participants in order to evaluate the components of the proof image. The researcher used this method to obtain in-depth information by asking more questions in addition to the questions listed in the interview form that he has prepared. This method ensured an open-ended interview process during which new discoveries could be made depending on the responses of the participants. The questions used in the interview form were developed in accordance with the feedbacks from two experts and their validity was confirmed by using a pilot study conducted before the tasks. Furthermore, the participants themselves also provided support especially in the process of evaluating the feeling dimension of the proof image. Clore (1992) defines the concept of feeling as all "internal" signs that provide usable feedback or information coming from the bodily, cognitive or affective states. Clore's definition (1992) was used as a reference for the affective analysis conducted in this study. Since the feelings are internal signs, it is more difficult to evaluate them externally. Thus, it is considered to be more objective to allow the participants themselves to assess their own feelings (i.e. suspicion, doubt, happiness, anxiety etc.). After the completion of each proof process, the researcher showed them "the video recordings of their faces" and asked them to fill in their feeling charts and submit the charts as soon as possible. The feeling chart is provided in the form of a table in order to help the participants to match their feelings with the relevant events of the proof process. Furthermore, before starting the tasks, the researcher provided preliminary information about the definition of feeling and how to fill in this table. Thanks to this, the researcher was able to collect data that allowed the indepth analysis of the proof processes in terms of cognitive and affective dimensions and proof images.

After data were collected, the analysis process began. Transcription was carried out together with the analysis process. At this stage, descriptive analysis method was used in order to classify the actions carried out by the prospective teachers according to the categories (cognitive and affective categories) as suggested by Kidron and Dreyfus (2014). According to Yıldırım and Şimşek (2013), descriptive analysis summarizes and interprets data in line with the predetermined themes, and then some conclusions will be reached by examining the cause and effect relationship. In order to ensure the reliability of the coding process (at the end of each proof task), the researcher obtained feedbacks from the field expert and made the necessary corrections accordingly. The results of the analysis revealed that while the participant " $\mathrm{F}$ " had no proof image in both tasks, the participant "N" had the proof image in both tasks and the participant "Ç" was able to develop a proof image in the second task (after receiving formal information) although she had no proof image during the first task, Since this study aims to assess the effect of formal information on the formation of proof image, only data about the participant Ç will be shared.

\section{Findings}

This section presents the data obtained from the analysis of the proof processes of Ç in the first and second task. At this stage, the proof processes are discussed first and the findings are revealed after examining the components of the proof image. The sub-categories of cognitive dimension of the proof image are evaluated by using epistemic actions including the individual's intuition, discourse, actions, and attitudes. This section also discusses the intuitive conviction dimension of the image and especially the feelings in this context, in line with Clore's (1992) approach. The researcher primarily uses the interview data and responses given to the feeling charts for the assessments made at this stage. Furthermore, in some cases, the expressions and mimics of individuals are also evaluated in order to elaborate on the dimension of the feeling.

\subsection{Task I - Ç's Proof Process}

After reading the question at the beginning of the proof process, $C$ first started to think about the concept of infinity and infinite sets. After Ç remained silent for a while, she defined the infinite set as "a set whose elements are infinite". She also noted that the sets of integers $(\mathbb{Z})$, rational numbers $(\mathbb{Q})$ and real numbers $(\mathbb{R})$ could be good examples. After that, she gave a specific example in order to clarify the general question and asked herself that "So integers and rational numbers ... Both are infinite sets. Are these sets equivalent?" At this stage, she started to think about the concept of "equivalence". She defined equivalent sets as "sets with the same number of elements" and mindfully wrote the following sentences:

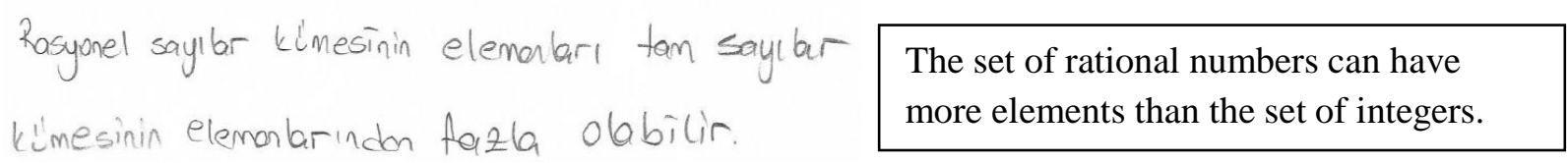

Figure 1. Ç's initial line of thought with regards to the sets $\mathbb{Z}$ and $\mathbb{Q}$

When she was asked to explain how she reached this conclusion, Ç noted that "every integer is a rational number, but may not be the other way around". However, she used the word "may" instead of making a definitive judgment. When the researcher asked her why, she said that "we cannot count the number of elements 
that infinite sets have. But at first glance, the number of elements in the rational numbers seems to be more". At this point, she summarized the main reason of her dilemma as follows:

The first thing that came to my mind was that the rational numbers had more elements... But since both are infinite sets, I think we cannot count their elements. I cannot say that one infinite set is bigger than another. I cannot make a comparison between the infinites ... But since both sets have infinite elements, they are probably equivalent.

At this point, she realized that her examples put her in a deadlock situation, and decided to include the real numbers $(\mathbb{R})$ into the thinking process. However, after she faced a similar challenge again, she was unable to overcome it. At this point, she noted that examples of sets having "subset relation" created confusion and did not help her. Then, she thought about it a little bit more and decided to create the following visual model (a number line), in order to interpret the relationships on sets:

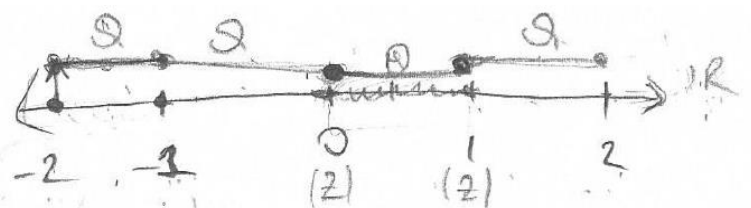

Figure 2. Ç's drawing that focuses on sets and shows the relations between them

On this model, she specifically focused on the gaps between the integers. After a while, she felt both surprised and happy and said that "Both real numbers and rational numbers covered the entire number line. Therefore they can be equivalent". However, at this stage, she came to the conclusion of the set of integers cannot be equivalent to these sets (since it contains spaces between its elements). On the other hand, she found these two examples insufficient to reach a general conclusion and decided to question the similar relationship again in terms of different infinite sets. At this stage, the first sets that came to her mind were odd numbers and even numbers. Similarly, she also showed these sets on a number line (see. Figure 3) and decided that they should be equivalent by considering the relationship between the consecutive elements.

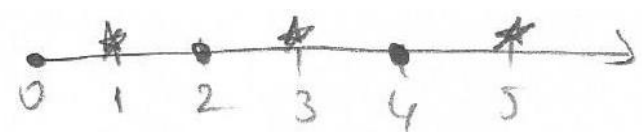

Figure 3. Ç's drawing that shows the equivalence of sets of odd and even numbers

On the other hand, although she stated that these examples were sufficient to convince her about the equivalence of the infinite sets until this stage, she could not reach a definite result for the situation of "not being equivalent" with a sad attitude. She noted that the figure she created for the integers $(\mathbb{Z})$ and rational numbers $(\mathbb{Q})$ might be misleading and made the following explanation:

When I look at it on this figure, I think these (she refers to odd and even numbers) are equal. But I think the integers and rational numbers are not equal. (With indecisive tone) I think this figure misleads me. As we express it verbally, infinite element is equal to infinite element.

After this explanation, she remained silent for a while and continued her line of thinking by focusing especially on the first line she drew. After a while, she made the following explanation by pointing again the spaces between the integers in the number line with the tip of her pen:

Rational numbers have infinite elements that are not integers. When we subtract them from the rational numbers, only integers will remain. This means subtracting infinity from infinity, which leads to uncertainty.

At this stage, she attempted to find an answer to her question of $\infty-\infty=\infty$, but after some simple attempts, she gave up. She explained why she could not continue with the proof process, as she had never thought about the mathematical meaning of the " $\infty-\infty$ " (and why it is uncertainty). Therefore, she said that she did not have sufficient information to continue with the proof and ended this process by writing the following sentences.

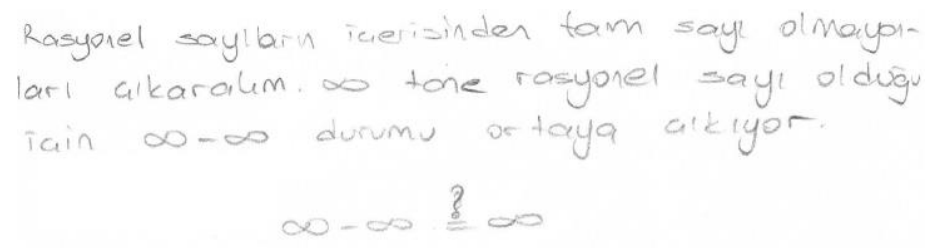

When we subtract integers from rational numbers, infinity minus infinity situation occurs since there are infinite rational numbers.

Figure 4. The uncertainty $\infty-\infty=\infty$ determined by $C$ in the context of sets $\mathbb{Z}$ and $\mathbb{Q}$ 


\subsection{Task I - Evaluation of Ç's Proof Image by Its Components}

Before the first task, the instructor did not provide any preliminary information about the concept of equivalence proposed by Georg Cantor. This practice aimed to find out whether the participants could develop a proof image in their own without sufficient preparation. On the other hand, analysis results revealed that Ç could not develop a proof image during the first task. The results obtained in the context of sub-components are presented below.

\subsection{1. $C_{1}-$ Being Personal}

After examining Ç's proof process, it can be said that Ç's unique way of thinking guided the process. In other words, she attempted to prove her own ideas instead of using an approach taken from any external source (teacher, book etc.). She tried to develop her own arguments regarding the accuracy of her claims at the each stage of the proof. Therefore, it can be concluded that final product was created as result of Ç's own cognitive efforts and therefore her image had the characteristic of personal understanding. In addition to this, the fact that she clearly stated that she had not seen a similar proof before in interview, can also be considered as one of the indicators of this characteristic.

While developing her understanding, Ç tried to reach a comprehensive conclusion by considering specific examples for a general problem related to "every infinite set". For this reason, it can be said that these examples had shaped her understanding to a great extent. Thanks to these examples, Ç was able try different approaches and she determined that some infinite sets can be equivalent. However, she was unable to answer some questions or made only superficial explanations with intuitive responses, largely due to her inadequate knowledge. Therefore, it can be said that although she was able develop an understanding, she had difficulties in terms of deepening it. Hence her proof process was inconclusive.

\subsection{2. $C_{2}$ - Including Logical Links}

When the proof process is examined, it can be said that Ç performed a proof activity that started with informal components instead of formal mathematical understanding in general. In this process, she recognized (R-) many mathematical structures in accordance with her personal understanding and used (B-) them at several points in order to make a progress in the proof process. This characteristic can be observed at many different points in her proof process. For example, the sub-set relationship between the elements of the set of integers and the elements of the set of rational numbers can be seen as an example of this characteristic. On the other hand, she was not able to establish the expected formal relations at several points due to her insufficient knowledge regarding Cantorian Set Theory. Ç could not go beyond the definition of "sets with equal number of elements are equivalent sets" which is a definition valid for finite sets and she could not use the idea of a "bijective mapping" proposed by Cantor. Moreover, there were several erroneous and inadequate relationships based on the concept of infinity during the process. For example, Ç was not able interpret the " $\infty-\infty$ " situation at the last stage of the proof in terms of equivalence. In addition to this, it can also be said that she was influenced by her intuitions as well as her formal thinking style in terms of relations established by her. For example, when she compared the sets of rational numbers and integers, she considered the spaces between the integers and said that these two sets cannot be equivalent. This explanation can be considered as an example of intuitive approach. Furthermore, it can also be said that $C$ reached a dead end due to her insufficient mathematical knowledge to verify or falsify her intuitions. For example, when she considered her visual intuitions, she described odd and even numbers as "equivalent" infinite sets, but rational numbers and integers as "non-equivalent" infinite sets. Therefore her intuition of "every infinite set is equivalent" displayed an indecisive fluctuation, sometimes getting stronger and sometimes weakening. This can be considered an important factor explaining her inability to end her proof activity.

\subsection{3. $C_{3}-$ Being Dynamic}

In the process of proof, $C$ used her intuition that every infinite set should be equivalent and tested the accuracy of her intuition by using different examples (odd numbers - even numbers, rational numbers - integers etc.). At this point, she could take her proof process from simple connections with few components (basic concepts, axioms etc.) to a more complicated level that contains more components (relation networks, feelings, etc.). However, she followed a process guided by her intuitions due to her lack of formal knowledge to explain certain points needed in the proof process. In other words, she was not able to reach the expected "justification" level, which links mathematical information. This weakened the hierarchical connections established between the phases of the proof process and hindered the formation of a comprehensive proving method. Therefore, it can be said that $C$ has obtained a static image consisting of discrete structures that contain partially consistent connections. Following explanation, which she made at the end of process, shows that she had a branched process of proof, which is divided into different branches, instead of following a spiral (dynamic) development:

I tried to find a contradiction without success. Sometimes my mind followed other directions, but I couldn't reach a conclusion. 


\subsection{4. $\mathrm{C}_{4}$ - Integrity (Giving Rise to an Entity)}

Due to the deficiency of dynamic development in her proving activity, Ç could not reached a holistic picture and thus her proof image lacked integrity. Furthermore, her image had separate image parts. Due to this fragmented image, it can be said that Ç could not carry the stages of proof in her mind as a whole, and she experienced some contradictions when she tried to use the conclusion she had reached in the previous stages. For example, as a result of her actions she realized that odd numbers and even numbers could be equal (on the number line), but could not form a definite judgment in terms of integers and rational numbers. Moreover, in terms of the equivalence of infinite sets, she made two different interpretations, one based on the "sub-set relation" and the other one based on the "single infinity intuition" and she preferred to end the process since she could not find any evidence that could falsify any of them. In this context, especially the inability to reach a conclusion and "incomplete" proof process can be considered as an important indicators of the lack of this characteristic. Due to this defectiveness, Ç also could not experience inspiring moments (insight and enlightenment). Because the basic components, which allowed inspirational moments such as "a comprehensive view of the process", "establishing connections with previous stages" and "being able to predict the next stages", were missing.

\subsubsection{Intuitive Conviction}

Ç experienced various affective states due to the cognitive fluctuation she had during the proof process. Although she had an intuition that infinite sets should be equivalent at the beginning, she could not convince herself. Because she could not reach the desired results when she questioned this intuition at certain points. However, it can be seen that she had some positive feelings at certain points, when she tried to confirm her thoughts. She revealed them both in her explanations during the interview and in the notes she made on her feel chart. For example, when she saw that "the odd and even numbers should be equivalent" on the number line she drew, she justified her intuition about the equivalence of the sets and stated that she was feeling on the right track. However, when she compared the integers and rational numbers on the same figure (considering that there are infinite rational numbers between the two integers), she realized that these sets should not be equivalent and saw that this contradicted the intuition of "all infinite sets are equivalent". She noted in her feeling chart that she had "feeling of suspicion". On the other hand, she ended the proving process by stating that she did not have enough information to resolve this contradiction.

\subsection{Task II - The Proof Process of Ç}

Ç read the question with a smile on his face at the beginning of the second task and then explained what she learned in the course presented before the task, as follows:

The equivalence means the number of elements was equal, but when there is a bijective function between two sets, they would also be equivalent. We gave examples of this in the class.

At this point, she noted that the definition of equivalence that is valid for finite sets $(A \equiv B \Leftrightarrow n(A)=n(B)$ ) cannot be applicable for infinite sets, and she gave examples of bijective matches she learned in the course as follows (P: Prime Numbers):

$\begin{aligned} f(x)=x & \rightarrow x \text {. asa } 1 \\ 1 & \rightarrow 2 \\ 2 & \rightarrow 3 \\ 3 & \rightarrow 5 \\ \mid N & \sim \mathbb{P}\end{aligned}$

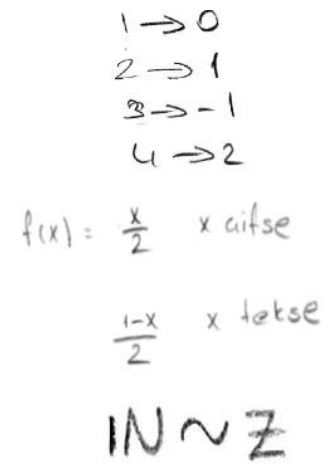

Figure 5. Example matches noted by $C$ for $\mathbb{P} \sim \mathbb{N}$ and $\mathbb{N} \sim \mathbb{Z}$ for she learned at class

After giving these examples, she focused on the question again and realized that her examples did not provide an adequate answer for "every infinite set" and explained that "there might be infinite sets that I do not know of and they may not be equivalent". Furthermore, she began to rethink the question of $\mathbb{Q} \sim \mathbb{R}$, for which she could not find an exact answer in the previous task, saying that if she could find a suitable example, she could answer the question. First, she summarized her previous approach and stated that "I showed them both on the number line. I've made a match. I said the numbers of elements are equal". She also noted that this time she 
would focus on bijective match. Although she tried to form some functions (such as $f(x)=x$ and $f(x)=x^{2}$ ) between two sets, she refrained from making a definite judgment about equivalence, taking into account that they did not meet the requirements of being bijective. At this point, she changed her sample, stating that she had difficulty thinking about the sets she chose. At the next stage, she tried to find an answer to $\mathbb{Q} \sim \mathbb{Z}$ question. Firstly, she considered the elements of integers and the elements of the rational numbers and stated that she needed to write down a fractional function and then, she defined the mathematical expression of " $\mathrm{f}: \mathbb{Q} \rightarrow \mathbb{Z}, \mathrm{f}(\mathrm{x})=$ $\frac{1}{x}$ ". At this point, after thinking for a while, she said it would not be a valid function. When she was asked about the reason, she gave the following answer: "For example, if I took $1 / 2$, it will go to 2 . But if I had $\frac{2}{3}$ it would go to $\frac{3}{2}$ and it is a rational number as well'. As to the comparison between rational numbers and integers, she said, "it seems that there are more elements in the set of rational numbers". Then she remained silent for a while and examined the examples she gave from the beginning of proof process and determined that the "sub-set" relationship did not create any problem in terms of equivalence of sets. At this stage (as in the previous task) by hoping that drawing diagrams might work, she drew a number line and then made the following explanation:

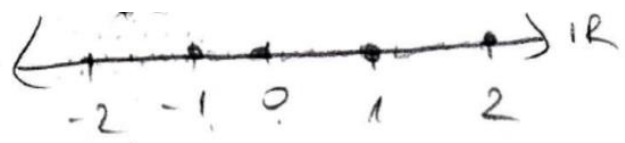

Figure 6. The number line formed by $C$ to reflect on sets $\mathbb{Q}$ and $\mathbb{Z}$

(Sighing) But... Rational numbers are infinite. Let's say I matched a number from here (referring-2 to 1 ) to that (referring to -2 ). I matched another one with this one (referring to the number -1 ). I think the numbers in between (other rational numbers between -2 and -1 ) will remain unmatched. We may not find an integer to match them. When we look at the figure...

Later on, by deepening her drawing approach, she started to think about how a function graphic can be defined between these two sets. While drawing a coordinate plane, she expressed her thoughts out loud and made the following explanations:

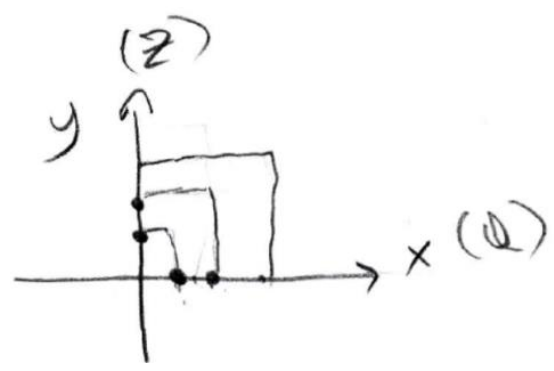

Figure 7. Graph created by Ç for a function that can be defined between the sets $\mathbb{Q}$ and $\mathbb{Z}$

If I take a point from here (marking a point on the $\mathrm{x}$ - axis), it will match to a point from there (marking a point on the $\mathrm{y}$ - axis). I mean it will match... (By noticing something) But a rational number may be present here showing the points on the $\mathrm{x}$-axis) between the two rational numbers (?).

While examining the axes, she realized that although she knew that "there was no other integer between two integers," she could not impose such restrictions for the rational numbers. However, she did not want to proceed without mathematically verifying this hypothesis. At this point, she started to think whether there are successive rational numbers similar to the successive integers and she chose the unit fractions of $\frac{1}{3}$ and $\frac{2}{3}$ as an example. After thinking for a while, she used the concept of equivalent fraction and illustrated that she could write a different rational number between two rational numbers she chose as follows, and thus realized that she was not mistaken in her intuition:

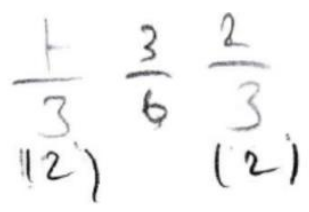

Figure 8. Another rational number specified by $C$ between two rational numbers 
On the other hand, this result also helped her to understand that the graphic she created between $\mathbb{Q}$ and $\mathbb{Z}$ was not actually a function, and therefore she concluded with a tone of disappointment that "Neither drawing function nor number line worked. I cannot form a function either. Maybe it's not equivalent". After this point, she focused on the sets $\mathbb{R}$ and $\mathbb{N}$ and stated that she would think about non-equivalence of the sets instead of the equivalence. When she was asked why she chose these sets, she made the following explanation:

I chose them; because this set $(\mathbb{R})$ is the biggest and the other set $(\mathbb{N})$ is the smallest... The set of real numbers includes natural numbers. The biggest of the including sets that I know of.

After thinking about the elements of the sets for a while, she drew a number line to see them as a whole. After trying to visualize how a bijective match could be, she made the following explanations:

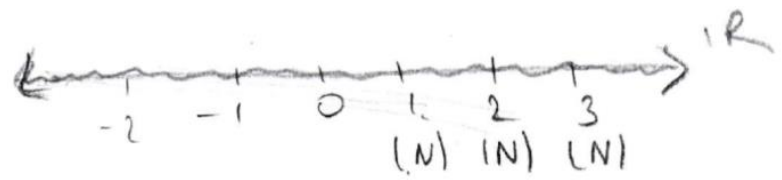

Figure 9. The number line drawn by $C$ to see the $\mathbb{R}$ and $\mathbb{N}$ sets as a whole

Here (on the left side of the number line, pointing to the far end of the range after the -2 element), I can match a real number at the end to 1 . I can match the next one to 2. I can continue like this. There are already infinite natural numbers.

However, she found it difficult to form an algebraic function for this match, which she had also difficult time expressing it verbally. After thinking for a while, she noted that she could not write a function with a pessimistic attitude. When she was asked about the reason of her pessimism, she summarized this difficulty and said that "... I have to check whether it is bijective here, but I can't. Since I can't even form a function". She stated that she could write down all the elements of natural numbers one by one, but she could not achieve this for real numbers. Then, by writing their some elements more clearly as follows, she continued to think about these sets:

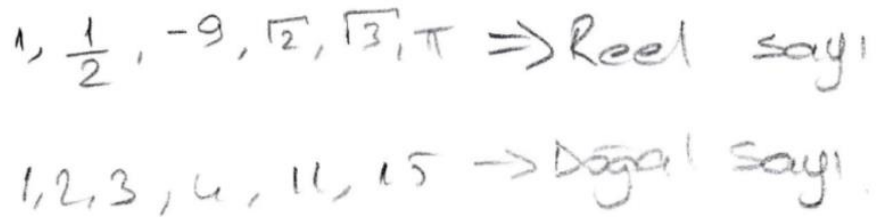

Figure 10. Some elements written by $C$ for $\mathbb{R}$ and $\mathbb{N}$ sets

At this point, she decided to create a visual matching in order to see the relationships between the elements. She chose successive elements from natural numbers and some of the real numbers, and made the following match:

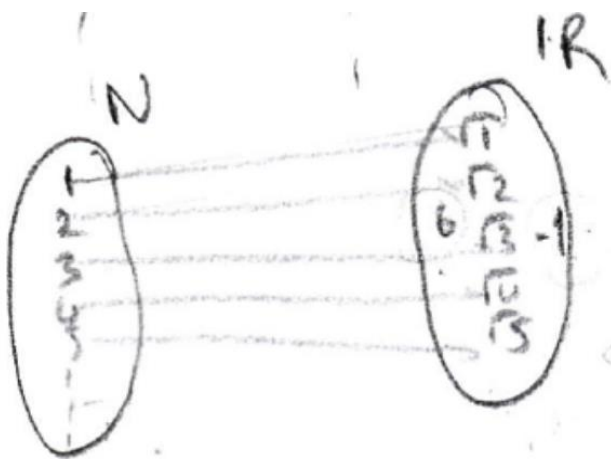

Figure 11. Ç's (visual) match between the sets $\mathbb{R}$ and $\mathbb{N}$

At this point, she pointed out the arrows that connected each natural number to the square root of this number and stated that this match can be expressed in the form $\mathrm{f}(\mathrm{x})=\sqrt{x}$. Moreover, she also said that although this was one-to-one, it could not be surjective in this way. When she was asked to elaborate on this view, she pointed out the elements " -1 " and " 6 " in the diagram (on the right side) that do not match any natural numbers, and emphasized that they remain unmatched. On the other hand, she started to question if the rule of the function to be changed, whether the remaining elements could be matched. She made different mental experiments considering that the set of real numbers would include other elements such as integers and rational numbers, as 
well as irrational numbers. After that, she made the following explanation, stating that even if the unmatched integers would be included in the match, the different elements in the real numbers would remain unmatched:

This is how I feel. They may not be equivalent. (Smiles) Since it doesn't work. When we take some of the real numbers, the other numbers will remain unmatched. No matter which rule I write, I think it will be like this. Some part will remain unmatched again. One-to-one criterion is satisfied, but surjectivity criterion will never be satisfied.

At this point, she refrained from reaching a general conclusion once again, and by taking into account the set of irrational numbers rather than the set of real numbers, she continued to reflect on the question of $\mathbb{I} \sim \mathbb{N}$. Similar to the previous case, she created an explicable matching between elements as follows (II: Irrational Numbers):

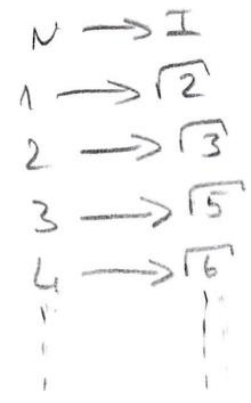

Figure 12. Ç's (visual) matching between the sets of $\mathbb{N}$ and $\mathbb{I}$

She immediately stated without hesitation that this mapping also could not be surjective either, since this time the elements such as " $\sqrt{2}+2$ ", " $\pi$ " and "e" would remain unmatched. After realizing the situation was very similar to the $\mathbb{N} \stackrel{?}{\sim} \mathbb{R}$ question, she explained her opinion with a definite judgment that natural numbers would never be equivalent with the real numbers as follows:

Even if I work until the morning, I cannot write a function. Surjectivity criterion will never be satisfied ... Unmatched parts will remain in the irrational numbers set. For example, " $\sqrt{2}+2$ " is an irrational number, but there is no natural number to match it. Moreover, if there are any unmatched elements left in the irrational numbers, the number of unmatched elements in the real numbers would be much higher. I think that's why it's not equivalent.

After this explanation, Ç reached the conclusion that there could be infinite sets which were not equivalent to each other and completed the proof process by writing the following explanation with a happy facial expression:

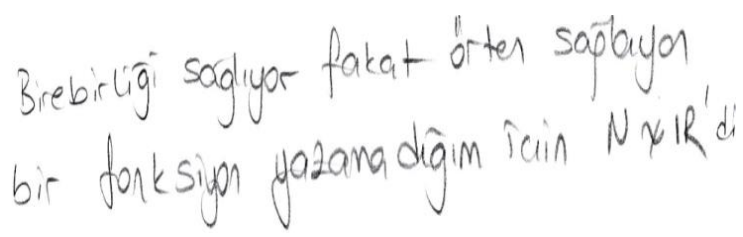

One to one match criterion is satisfied but since I cannot form a surjective function $\mathbb{N}$ is not equivalent to $\mathbb{R}$.

Figure 13. Ç's conclusion at the end of the proving process

\subsection{Task II - Evaluation of the Ç's Proof Image by Its Components}

The second task was carried out within 24 hours after the first task. Prior to this task, no clue was given to the participants that the same problem would be addressed again. Furthermore, they specifically were asked not to do any research between the tasks and it was assumed that they followed this instruction. However, before the second task, the instructor gave them a lecture on the basic philosophy of the idea of cardinality. Therefore, the second task aimed to examine the components of the proof image that the participants would create (or could not create) after they had formal knowledge of the Cantorian Set Theory. Thus, it was aimed to elaborate the role of "formal knowledge" in the context of theoretical framework of proof image. Moreover, the results of the analysis revealed that $C$ did develop a proof image in this task. The results obtained in terms of the sub-components are presented below.

\subsection{1. $C_{1}-$ Being Personal}

When Ç's proof process is examined, it can be said that she repeated the examples given in the class and used them as a starting point. Thus, she was able to create her own unique approach by using the conclusions drawn from the basic information she obtained during that class. One of the most important indicators of her unique 
approach is her willingness to think about different examples. The questions that Ç asked during the proving process are summarized in the table below:

Table 2: The distribution of questions that Ç sought to answer during the Task II

\begin{tabular}{c|c}
\hline \multicolumn{2}{c}{ Questions that Ç Tried To Answer During the Proof Process } \\
\hline Questions Answered in the Course & Questions Unanswered in the Course \\
\hline $\mathbb{N} \sim ? \mathbb{P}$ & $\mathbb{R} \sim \mathbb{Q}$ \\
$\mathbb{N} \stackrel{?}{\sim} \mathbb{Z}$ & $\mathbb{Q} \sim \mathbb{Z}$ \\
& $\mathbb{R} \sim \mathbb{N}$ \\
& $? ? \mathbb{N}$ \\
\hline
\end{tabular}

She preferred different infinite sets in an attempt to reach a generalization that may apply to "every infinite sets". Based on the presented table, it can be concluded that Ç did not limit the relationships regarding the equivalence of infinite sets with the examples she had seen in the class and could go beyond them. Furthermore, she was able to broaden her perspective by trying different approaches and reflecting on several and different examples. Thus, she could express them in an increasingly formal framework.

\subsection{2. $C_{2}$ - Including Logical Links}

When Ç's proof process is analyzed in a holistic way, it can be said that she chose (R-) various mathematical structures in order to deepen her understanding (recognizing) and used them (B-) by making connections based on logical justification. In addition to this, when these recognized and used structures are examined, it can be also said that Ç was highly influenced by the course presented before the second task. For example, the concept of "function" is one of the clear indicators of this situation. Although it did not emerge in the first task, this concept was used effectively in the second task. Ç did not address this concept alone and used (B-) it by mostly associating it with the bijectivity. However, it can be said that she adopted an approach that relied heavily on formal mathematical tools compared to the first task. For example, when examining the relationship between sets $\mathbb{Q}$ and $\mathbb{R}$, after defining the function "f: $\mathbb{Q} \rightarrow \mathbb{R}, \mathrm{f}(\mathrm{x})=\mathrm{x}$ " she made the following explanation, which can be considered as an example of a formal approach:

But if I actually wrote... $\mathrm{f}(\mathrm{x})=\mathrm{x}$ here, it would be one-to-one, but it wouldn't be surjective. Since the elements in the real numbers set would remain unmatched. This example does not work. Real numbers... Include the natural numbers and also include the integers. There are rational numbers. There is also irrational numbers. There are always some elements in real numbers, which remain unmatched.

In this explanation, Ç benefited from the formal relations and examined "bijective function properties" in the context of domain set and the image set. Primarily, she thought about the sets themselves and then inferred that if the function formed with the rule $\mathrm{f}(\mathrm{x})=\mathrm{x}$ " was defined as $\mathbb{Q} \rightarrow \mathbb{R}$, there would be unmatched elements in the real numbers and thus this match could not be surjective. It can be said that similar formal inferences contributed to Ç's search for the proof significantly. As she avoided making assumptions between the concepts she selected (R-) she was able to obtain a justified relation network. During the interview conducted at the end of the proof process, she summarized the framework of the relations she established between the concepts as follows:

Since I was asked about the equivalence, I had to use the concept of bijectivity and for this I needed to use the concept of function. I must also define a function from one set to another. I used them by making a selection from the number sets such as the sets of integers and rational numbers.

On the other hand, when the proof process is examined, it is found that Ç sometimes established incomplete or incorrect relations. For example, when she examined the equivalence between $\mathbb{Q}$ and $\mathbb{Z}$, she also considered the definition of rational numbers, and formed the expression of " $\mathrm{f}: \mathbb{Q} \rightarrow \mathbb{Z}, \mathrm{f}(\mathrm{x})=\frac{1}{x}$ ". Thus she thought that all rational numbers could be matched with integers. However, after examining the results of several elements and evaluated domain-image sets together, she realized that this matching could not be a function. Thus, she continued her search for different examples from which she could verify her intuition of "equivalence". Although the "incorrect relation" delayed the process, it did not prevent her to reach the formal proof since she was able to identify this inconsistency in the relationship network and to eliminated it before moving on to the next phases of proof. 


\subsection{3. $C_{3}-$ Being Dynamic}

When the proof process and especially the quality of the connections made in this process are considered, it can be concluded that Ç's proving activity has shown a dynamic development. In particular, she questioned the "cause-effect" relationships at every stage of the proof process and avoided making any assumptions. Thanks to this, she was able to establish consistent relations between the previous phases of the process and next phases of the process. For example, after her approaches focusing on "equivalence" failed, she decided to focus on the "non-equivalence" instead and preferred to use extreme examples. At this point, she chose (R-) a set of real numbers $(\mathbb{R})$, which is a large set of numbers, and the set of natural numbers $(\mathbb{N})$, which she thinks is a smaller set, and imagined how they can be matched. After thinking for a while, she also considered the irrational numbers in the real numbers, she defined the function of "f: $\mathbb{N} \rightarrow \mathbb{R}, \mathrm{f}(\mathrm{x})=\sqrt{x}$ " and formed a visualized diagram. As a result of all these steps, although she used all of the natural numbers she realized that the elements remained unmatched in the set of the real numbers and gained a strong intuition that these sets could not be equivalent. As shown by this example, Ç achieved a consistent development from simple to complex structures, by including the previous phases into the later phases of the proof process. Thus, it was observed that $C$, who could not even determine a proof method in the previous stages, implemented a proof method based on the counterexample approach. Especially in the last stages of the process, it was important that she could not show the equivalence of the natural numbers with irrational numbers. At this point, she was able to consider the result she obtained at the previous phase and concluded that "if natural numbers cannot even match irrational numbers, they cannot be equivalent to real numbers" and she completed the proof process in a short time by realizing that she obtained a counterexample.

\subsection{4. $C_{4}$ - Integrity (Giving Rise to an Entity)}

When the proof process is evaluated in terms of integrity characteristic, it is found that Ç had this exact characteristic. She saw the process of proof in the second task as a continuation of the first task and made decisions by comparing her actions with the previous ways of thinking as appropriate. Thus Ç made connections with the previous phases as necessary in the proof process, thus guiding the process holistically. For example, after her negative experiences in the first task, she avoided thinking about irrational numbers for most part of the second task. This shows that she used her conclusions gained from experience and guided the proof process accordingly. On the other hand, thanks to her dynamic development, she was able to consider the proof process as a whole in one-single form (instead of fragments) and hence she could elaborate on the proving steps. As she reached an intuition that infinite sets would not be equivalent and when she failed to show the equivalence natural numbers set with the irrational numbers set, (thanks to the holistic view she had) she understood that natural numbers were not equivalent to the real numbers and expressed it with appropriate representations. If a holistic image had not appeared, it would not be possible for her to establish the link between the two conclusions she reached at different times and complete the proof process. On the other hand, Ç used a criticalformal approach in the proof process, established a justified relationship network and kept the elements of proof as a meaningful whole in her mind. Hence she was able to develop her insights and experienced enlightenment. Her first insight began to develop when $C$ could not show the equivalence of the sets $\mathbb{Q}$ and $\mathbb{Z}$ after she successively gave the examples which she initially considered to be equivalent. However, she was able to reveal this insight -realization- precisely by defining the function of " $\mathrm{f}: \mathbb{N} \rightarrow \mathbb{R}, \mathrm{f}(\mathrm{x})=\sqrt{x}$ " while she was searching an

answer for the question of $\mathbb{R} \sim \mathbb{N}$. When $C$ formed this function with a visual diagram between the two sets, she realized that many elements in the range would remain unmatched, and felt for the first time that infinite sets could not be equivalent. During the interview held at the end of the proof process, she explained this insight as follows:

... until I drew this (by showing the diagram match between the sets). I thought they could be equivalent. I drew the number line, but it didn't work. But when I drew these sets, I saw that there were unmatched elements (that's when I realized)...

On the other hand, despite this initial strong suspicion of "non- equivalence", she was afraid to reach a definite conclusion at that stage and chose to continue the process of proof. However, she had experienced enlightenment when she observed that a similar problem was repeated again for the problem of $\stackrel{?}{\mathbb{I}} \stackrel{?}{\mathbb{N}}$ after a short time. At this moment, Ç realized that natural numbers could not be even equivalent to irrational numbers and therefore could never be equivalent to real numbers. At the interview following the process of proof, she summarized her experience contributed to this enlightenment as follows:

I think they are not equivalent. When we chose natural numbers, we found that some real numbers remained unmatched. Then we moved to the irrational numbers. Likewise, we have matched the natural numbers to the irrational numbers one-by-one. However, there were also elements remained unmatched here: like " $\sqrt{2}+2 "$. No matter how many natural numbers I use, there will be unmatched irrational 
numbers. If I can't match them (she means irrational numbers), then I can't match with the real numbers at all.

Thanks to this enlightenment she experienced, she was able to reach a definite conclusion in terms of proof process, she constructed (C-) a new knowledge and finally completed the proving process. The new knowledge mentioned here refers to the fact that "the infinite sets which are not equivalent can also exist".

\subsubsection{Intuitive Conviction}

Formal knowledge, which Ç acquired before the Task II, contributed to her cognitive understanding in many ways and it also had several affective influences. As one of the most important indicators of this development, she used fewer assumptions during the Task II, compared to Task I. During the Task II, she firmly maintained the cause and effect relationships. Thus, she was able to achieve progress in the proof process by displaying an attitude of "critical thinking" at certain points in her decision process. Moreover, she paid more attention to feeling "convicted" at every stage of the proof, and therefore she focused on less convincing points instead of avoiding them. For example, after thinking about the natural numbers and real numbers for a while, she could not reach a conclusion, and then made the following explanation with a pessimistic tone of expression:

I ran out of examples. (Laughs) The infinite sets that I know of have run out. Is my way of thinking so simple? Do I only think about very small portion of it? (She quietly starts to think about it.)

Although this explanation was interpreted as an indication of the negative feelings that she experienced, Ç did not give up at this point and continued to focus on how a possible bijective matching could be defined between the sets. After a while, she realized that she could make a visual matching even though she could not form an algebraic function and started the process that resulted in insight and enlightenment. Moreover, thanks to this approach, it was observed that she could experience positive feelings (being on the right track, knowing, rightness etc.) at several points in the process. During the interview held at the end of the proving activity, although she stated that the feeling of being on the right track was interrupted when she questioned the equivalence of natural numbers and rational numbers, she noted that she was able to experience this feeling

again more strongly, especially when she was thinking about the question of $\mathbb{R} \sim \mathbb{N}$. On the other hand, she said that the feeling of rightness was predominant especially for the examples, which she learned in the course and gave at the beginning of the proof process. However, although she could not experience this feeling for a while, she felt this very strongly once again thanks to the function of " $\mathrm{f}: \mathbb{N} \rightarrow \mathbb{R}, \mathrm{f}(\mathrm{x})=\sqrt{x}$ " as she noted in her feeling chart. Furthermore, she emphasized that for the first time she had doubted that infinite sets might not be "equivalent" thanks to this function. Accordingly, she responded to the question about whether the feeling of certainty has arisen at any point, during the interview as follows:

(Without hesitation) I felt it since I used a smaller set, the set of irrational numbers. I thought if it did not work here, it would not work for the real numbers as well, when I chose a bigger sample.

As it can be seen from the explanation, the feeling of certainty accompanied the moment of enlightenment. She definitely understood that infinite sets could not be equivalent at this point and she was able to express this mathematically. Moreover, unlike the previous task (Task I), she was able to reach a conclusion, and thus she said that she completed the proving process.

\section{Discussion, Conclusion, and Recommendations}

In this study, two different proving activities related to the same question examined in the context of the proof image framework, which introduced by Kidron and Dreyfus (2014). Although the participant, who named Ç, had enough preparation for the second task, she did not has enough pre-knowledge for the first task. Both activities were analyzed in terms of both affective dimension that included intuition and feelings, and the cognitive dimension that included the moments of insight and enlightenment. As a result of these examinations for Task I and Task II, similarities and differences between them were identified. The most important similarities were that she attempted to achieve a specific purpose in line with her personal understanding, she selected (R-) certain mathematical structures and established relationships (B-) between them. Considering the relationship between proof and different types of knowledge (Dreyfus, 1999), it can be said that these logical connections between the concepts served the purpose of "using knowledge effectively". As stated by Barnard and Tall (1997), proof requires a synthesis of various cognitive connections to create a new connection. Furthermore, it can be interpreted that her understanding related to the equivalence concept in the second task, where she had sufficient pre-knowledge, was deeper and more comprehensive compared to the first task. In particular, it can be concluded that thanks to the expansion of her perspective she was able to increase the number and diversity of the samples in the second task. In this way, she made different types of inquiries and directed her proof process according to various findings she obtained. On the other hand, it can be said that in the second task, where she had sufficient formal knowledge, she emphasized the "cause-effect" relations between the concepts by keeping 
the heuristic assumptions in the foreground and thus reached a justified relation network. This led to a differentiation in the context of the characteristic of "dynamism", one of the most important differences identified between the two proof processes. Thanks to this justified relationship network, Ç's proof image in the second task evolved from an undeveloped form to complex form, from simple to complex, in line the views of Davydov (1990) on abstraction. Interaction of discrete parts in the first task and the dynamism, which enabled a synthesis (C-) as a result of justified connections established during the second task, can be visualized as follows:

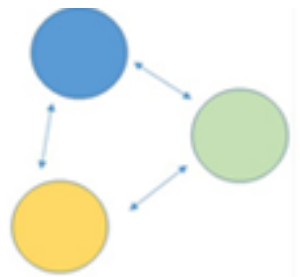

Task I

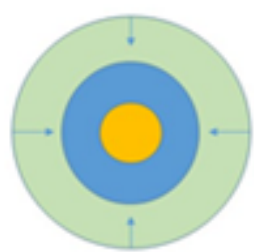

Task II

Figure 14. Static Structure (Task I) and Dynamic Structure (Task II)

At this point, it can be said that due to the absence of dynamism in the first task, $C$ failed to establish sufficient connections between the results, which she obtained from different examples, and therefore she had difficulty in terms of developing a proving method. Similarly, McKee and Selden (2010) also observed that when a student did not know what to do next in the proof process, s/he would do something incomprehensibly related to the theorem. Moreover, the image that emerged during Ç's second proof process provided her with the insight that allowed her to understand why her argument was correct and thus she felt a need to go beyond her intuitive approach to obtain a formal view. Thanks to this intrinsic motivation, she started to express her thoughts with more appropriate language, using formal tools such as definitions and notations. This also explains the process conducted after she developed the visual matching in the second task. At this stage, as expressed by Kidron and Dreyfus (2014), it was possible to move to a more formal dimension from an informal dimension since the formal structures (axioms, definitions, theorems, hierarchical relations etc.) supported the weaker structures (single examples, assumptions, intuitions etc.).

Another important difference between the two tasks was the integrity (giving a rise to an entity) characteristic. According to Kidron and Dreyfus (2014), when an image reaches integrity, it carries the whole mathematical situation in its entirety. Contrary to the first task, it can be said that Ç was able to carry her actions and results, which she reached in the previous stages, in her mind as a whole and thus she could experience an insight in the second task. This insight (and subsequent enlightenment) enabled her to reach a comprehensive conclusion in terms of the proof process. In addition to this, the inability to reach a definite conclusion during the first task was evaluated in the context of the lack of this characteristic. Furthermore, when the dimension of the feeling is examined, it can be said that she could successively feel the basic feelings such as feeling of familiarity, feeling of knowing, feeling of rightness and feeling of certainty that guided the proving actions at certain points in the second task and eventually she experienced a feeling of completeness for the whole activity. However, in the first task, it was found that in line with the difficulties experienced in cognitive actions, she could only experience some positive feelings momentarily and could not reach the feeling of certainty.

Considering the specific examples of this study, the main contributions of formal knowledge to the formation of the proof image can be summarized as follows:

- Formal knowledge contributes to the development of an intuitive understanding on why the argument is true.

- Thanks to formal knowledge, a unique proof approach can be identified.

- It can be provided arguments that can support ideas.

- The justified relations can be taken into account (instead of making assumptions), when moving between the stages of proof.

- The process of proof moves from an inconsistent form to a more consistent form.

- The proof evolves from simple structures to more complex structures.

- Insights and / or enlightenment can be experienced.

- The steps of proof can be elaborated with accurate representations.

- Positive feelings (being on the right track, knowing, rightness, certainty etc.) can be experienced.

- The feeling of completeness can be emerged.

- The proving process can be completed. 
It can be said that all of the contributions listed above are directly related to the components of the proof image. Based on these results, some recommendations that may trigger the proof images of prospective teachers in the proving practices are listed below:

$\checkmark \quad$ The conceptual background should be whole and complete.

$\checkmark$ Proving methods should be explained and their use should be demonstrated with examples.

$\checkmark$ Dynamic thinking styles should be encouraged by using different representation types.

$\checkmark$ The difference between assumption and evidence should be emphasized.

$\checkmark$ The instructor should explain the "justification" dimension, which is one of the main pillars of the proof process, and help the students to acquire the habit of questioning consistency during transitions between the proof steps.

$\checkmark$ The difference between proven and unproven situations should be emphasized.

$\checkmark$ The questionability of feelings / intuitions should be reminded frequently.

In addition to the above recommendations, it should be noted that providing formal knowledge may not be sufficient to ensure the certainty in terms of the formation of a proof image. In some of the tasks applied within the scope of the doctoral dissertation study, which is the main source of this study, it was observed that some of the participants did not have a proof image even after they had formal knowledge. These findings were not included here, since this study focused on the situations in which the image of proof emerged. On the other side, it was also observed in the presented study that $C$ did not reach a formal proof despite having a proof image during the second task. She focused on the relationship between natural numbers and real numbers, especially in the final stages of the proving process, and decided that these two sets were not equivalent. However, her approach was not considered as a formal proof since it did not include a formal generalization that no bijective matching can be formed between the two sets. Cantor (1891) was the first person to develop this proof, which was considered as a major breakthrough in the history of mathematics, by using diagonal matching. Since Ç used the concept of "infinity" in the context of bijective functions with the meaning suggested by Cantor, it can be concluded that she only made a verification as to proof. Therefore, more studies are needed to address the question of "How individuals can develop a formal proof after they obtain a proof image?". Furthermore, the understanding on nature of the concept of proof can be deepened by examining the proof images of different age groups and for different subject areas, as suggested by Kidron and Dreyfus (2014).

Ethics Committee Approval Information: Ethics committee approval was obtained from Dokuz Eylül University, Educational Sciences Ethics Committee for the research, with the date of 18/04/2019 and protocol number 2019/04. 


\section{İspat İmajının Oluşumunda Formal Bilginin Rolü: Sonsuz Kümeler Bağlamında Bir Durum Çalışması}

\section{Giriş}

Öğrenme sürecine dâhil olan bireylerin, çoğu zaman karşılaştıkları bir önermenin doğruluğunu ya da yanlışlığını nedenleri ile ortaya koymaları gerekmektedir. Bilginin gerekçelendirilmesi ile ilgili bu husus matematiksel düşünmenin ispat boyutu ile ilişkilendirilebilir. İspat, matematiğin anahtar bileşenlerinden biridir (Thompson, Senk ve Jhonson, 2009) ve matematik öğretiminde üzerinde oldukça zaman harcanan bir konudur. Çünkü ispatlar sayesinde matematiksel bilgilerin yeniden düzenlenmesi mümkün olmaktadır (Herbst, 2002). Bununla birlikte, matematik eğitimi literatüründe ispat kavramına ilişkin çeşitli görüşlerin ortaya çıktığı ve ispatın farklı boyutlarını ön plana çıkaran farklı tanımların alanyazında sunulduğu söylenebilir. En genel anlamı ile bakıldığında, matematiksel bilginin genelleştirilmesi sürecince izlenen yola "ispat" denebilir (Altun, 2005). Bununla birlikte ispatın "açıklama" işlevini vurgulayan Stylianides (2007) bu süreci, bir iddiayı doğrulamak ya da yanlışlamak amacıyla ortaya konan, birbiriyle ilişkili savlar dizisi olarak tanımlamaktadır. Diğer yandan, Harel ve Sowder (1998) ise bu sürecin gözlemlerin "doğruluğuna" ilişkin şüpheleri ortadan kaldırmak amaciyla gerçekleştirildiğini ifade etmiş̧lerdir. Dahası, Tall (1998) tarafından da belirtildiği gibi matematiksel ispatın temel işlevi, iddiaların mantıklı adımlar sayesinde bir sonuca ulaştı̆ııı göstermektir. Matematiksel aktivitenin özü olarak değerlendirilebilecek bu beceri sayesinde hem yeni matematiksel bilgiler ortaya çıkarılabilir hem de var olan diğer matematiksel bilgiler geliştirilebilir. Bu nedenle Almeida (2000) için ispat, matematiksel bilginin garantisini sağlayan temel bir aktivitedir. İspatın, matematiği öğrenmek için bir araç olması (Knuth, 2002) ise bu becerinin özellikle matematik eğitimcileri tarafindan sıkça vurgulanmasının önemli bir sebebi olarak gösterilebilir. İspat sayesinde, bir iddianın temelinde yatan (doğru veya yanlış) ilişkiler "nedensel" olarak açıklanabilir (Hanna, 2000) ve bu da ispatın "pedagojik" işlevinin önemli bir boyutu olarak değerlendirilebilir.

Öğretimin her seviyesinde büyük bir önem arz eden ispatlama aktiviteleri, özellikle üniversite düzeyinde de birçok matematiksel konunun öğreniminde ve öğretiminde önemli bir role sahiptir. İleri matematiksel konularda ispatlama yeteneği kritik yeteneklerden biri olarak kabul edilmekte (Weber, 2001) ve bu yeteneğin geliştirilmesi birçok dersin amaçları arasında yer almaktadır. Bununla birlikte, matematik eğitimi çalışmalarında ispatlamanın önemine sıklıkla vurgu yapılmasına rağmen araştırmalar üniversite öğrencilerinin bu konuda güçlük çektiğini göstermektedir. Söz konusu güçlüklerin sebeplerinden biri ispatın doğasına dair yetersiz anlayışlardır. Örneğin; Sarı, Altun ve Aşkar (2007) bireylerin ispat süreçlerinde dışsal-deneysel sonuçlara bağlı gerekçelerle yetinerek ispat hakkında eksik bir anlayış geliştirdiklerini belirlemişlerdir. Selden ve Selden (1995) ise üniversite öğrencilerinin, ispat süreçlerinde informal yaklaşımlarına bağlı kaldıklarını ifade etmişlerdir. Diğer yandan Attwood (2001) da yapmış olduğu tez çalışmasında organizasyon ve argümantasyon noktasında yaşanan eksikleri vurgulamıştır. Epistemolojik temelli benzer güçlüklere diğer araştırmacıların (ör., Almeida, 2000; Baker ve Campbell, 2004; Harel ve Sowder, 2007; Knapp, 2005) çalışmalarında da rastlanmaktadır. Bununla birlikte ispata dair güçlüklerin önemli bir bölümünün de başta hazırbulunuşluk (ön bilgiler, dil ve temsil kullanımı, muhakeme becerileri vb.) olmak üzere psikolojik veya pedagojik faktörlerden kaynaklı olduğu düşünülebilir. $\mathrm{Bu}$ noktada, matematik eğitimi literatürü incelendiğinde ispatlama aktivitelerinde "hazırbulunuşluk", "kavram yanılgıları" ve "üstbiliş" gibi bireysel faktörlerden kaynaklı başarısızlıklara dair çeşitli bulguların, pek çok araştırmacı (ör., Antonini ve Mariotti, 2007; Doruk ve Kaplan, 2017; Güler, Özdemir ve Dikici, 2012; Harel ve Sowder, 2007; Jones, 2000; Knapp, 2005; Ko ve Knuth, 2009; Pala ve Narl1, 2018a; Weber, 2006) tarafindan vurgulandığı görülebilir. Örneğin, Jones (2000) lisans düzeyindeki öğrencilerin ispatı oluşturmak için gerekli temsil ve gösterimleri yeterince içselleştiremediklerini ifade ederken Knapp (2005) ise bu düzeydeki öğrencilerinin matematiği formal düzeyde anlamadaki güçlüklerine vurgu yapmıştır. Diğer yandan Antonini ve Mariotti (2007) ise yöntemsel yetersizlikleri ön plana çıkarmıştır. İspat aktivitelerindeki bir diğer önemli noksanlık da bu sürece eşlik eden "sezgisel anlayışa" bağlı yetersizliklerdir (Moore, 1994). İspatlama sürecini açıklamaya çalışan birçok teorinin temelinde yer alan sezgisel yapılar, aktif anlama ve üretici düşünme için gerekli temel unsurlardandır (Fischbein, 1982). Bununla birlikte, Weber ve Alcock (2004) tarafından da ifade edildiği gibi gerekçelendirme aktivitelerinde formal düşünmenin bir tamamlayıcısı olarak sezgisel muhakemenin de kullanılması beklenmektedir. Sezgisel süreçlerin, formel süreçlere rehberlik etmesi sayesinde hem açıklayıcı hem de ikna edici nitelikte ispatlar (semantik ispat) oluşturulabilir. Aksi durumlarda, sezgisel anlayış ortaya çıkmadığında ispatın "ikna" boyutunun tam olarak ortaya çıkamayacağı da söylenebilir.

İspat sürecinde yaşanan ve bir bölümü yukarda sıralanan güçlüklerin araştırmacılar tarafindan ayrıntılı olarak ele alınması sayesinde ispatı farklı perspektiflerden değerlendiren birçok görüş sunulmuştur. Örneğin, ispat süreçlerinde bireylerin "gerekçelerini" derinlemesine inceleyen Harel ve Sowder (1998) ispat şemalarını ortaya koyarken bu süreçteki dilin kullanımı üzerine odaklanan Tall (1998) ise temsile dayalı bir sınıflama sunmuştur. Bununla birlikte; öğrencilerin kavramları, tanımları ve teoremleri biliyor ve bunları uygulayabiliyor olmalarına rağmen ispatı oluşturmada başarısız olabildiklerini gözlemleyen Weber (2001) ise stratejik bilgi kavramını tanımlamış ve bunun rolüne vurgu yapmışır. Diğer yandan, diğer araştırmacıların (ör., Güler ve Dikici, 2014; 
Harel ve Sowder, 1998; Hart, 1994; Weber ve Alcock, 2004) çoğunlukla ispatın bilişsel boyutuna ve bilişsel ürünleri üzerine odaklandıkları da görülebilir. Bu noktada, ispatlamanın aynı zamanda bir öğrenme aktivitesi olduğu dikkate alındığında bu sürecin "bilgi oluşturma" penceresinden yorumlanabileceği de düşünülebilir. Buna karşın literatür incelendiğinde yeni bir bilgiyi oluşturma sürecini temel alan ispat çalışmalarının yetersiz sayıda olduğu sonucuna ulaşılabilir. $\mathrm{Bu}$ tarz çalışmalar sayesinde sürece dâhil olan bilişsel faktörlerin, duyuşsal faktörler ile harmanlanarak derinlemesine analiz edilmesi ve çok boyutlu bir bakış açısının sağlanması mümkün olabilir. Ayrıca ispat sürecinin her aşamasının bireyler tarafından nasıl yapılandırıldığı belirlenebilir ve yaşanan güçlüklerin altında yatan sebepler daha iyi yorumlanabilir.

\subsection{Teorik Cerceve}

İspat becerisinden bağımsız bir matematik düşünülemeyeceği gibi (Schoenfeld, 1994) tüm öğrencilerin ispat süreçlerinde aynı süreçlerden geçmeleri de beklenemez (Weber ve Alcock, 2004). Öğrenenlerin ispat ile ilgili bilgi düzeyleri ve diğer ön yaşantıları farklı olacağından kendi özgün deneyimlerini ortaya koymaları beklenir. Bununla birlikte ispat süreci için birer dayanak oluşturan çeşitli unsurların (hazırbulunuşluk, stratejik bilgi, sezgisel anlayış vb.) bireyin zihnindeki kavram imajının birer parçası oldukları da söylenebilir. Çünkü kavramları esnek bir şekilde kullanabilmek için zengin bir imaja sahip olmak önemlidir. Dolayısı ile ispat aktivitelerinde başarı sağlanabilmesi için bireyin söz konusu kavram ile ilgili örnek olan veya olmayan durumlar, gerçekler, özellikler, ilişkiler, şekiller ve görseller gibi birçok şeye sahip olması beklenir (Selden ve Selden, 2007). Zengin bir kavram imajına sahip olmak ise bilgi oluşturma sürecinin doğru yapılandırılmasıyla mümkündür. Bu süreci sosyo-kültürel boyutları ile inceleyen Hershkowitz, Schwarz ve Dreyfus (2001) bilginin inşasını mikro-analitik düzeyde analiz edebilmek amacı ile bağlamda soyutlama (AiC) teorik çatısı kapsamında RBC soyutlama teorisini ortaya koymuşlardır. Bu bağlamda, yeni bir bilginin oluşum sürecinin sırası ile "Tanıma (R-)", "Kullanma (B-)" ve "Oluşturma (C-)" epsitemik eylemleri sayesinde mümkün olduğu söylenebilir. Soyutlama sürecinin ilk basamağını oluşturan Tanıma (R-), birey tarafından daha önce oluşturulan bir yapının problem çözme sürecinde fark edilmesidir (Türnüklü ve Özcan, 2014). Diğer yandan problemin çözümünü gerçekleştirmek için önceden oluşturulan matematiksel bir yapıdan yararlanılması ise Kullanma (B-) eylemi ile açıklanmaktadır (Schwarz, Dreyfus, Hadas ve Hershkowitz, 2004). Sürecin son aşaması olan Oluşturma (C-) ise önceki matematiksel yapıların kısmen değişime uğrayarak yeniden yapılandırılmasını ifade etmektedir (Bikner-Ahsbahs, 2004). Burada bahsedilen "yeniden yapılandırma" bir dikey matematikleştirme sürecine işaret etmektedir. $\mathrm{Bu}$ nedenle, Oluşturma (C-) eylemi sayesinde birey için daha önce ulaşılabilir olmayan "yeni” matematiksel bir yapının keşfi mümkün olabilir (Hershkowitz, Schwarz ve Dreyfus, 2001). Diğer yandan, bu keşif sürecinde "öngörülemeyen bir rastlantının” aksine matematiksel düşünme sürecinde yer alan bazı temel mekanizmaların önemli roller oynadığı yorumu da yapılabilir (Liljedahl, 2004). "Aha! Deneyimi" ve Aydınlanma, bilgi oluşturma sürecine eşlik eden söz konusu mekanizmalardandır. Aniden parıldayan bir elektrik kıvılcımı şeklinde imgeleştirilebilecek "Aha! Deneyimi” sayesinde öğrenenin zihninde hali hazırda yer alan bilgi yapılarının uygun bir seçilim ile bir araya geldiği ve bu sayede özgün bir fikrin aniden ve kesin biçimde ortaya çıkmasına olanak sağlandığı söylenebilir (Liljedahl, 2005). Ayrıca söz konusu bu yeni oluşum sayesinde bireyin içerisinde bulunduğu durumu daha iyi anlamlandırabildiği ve Rota (1997) tarafindan kullanılan anlamı ile aydınlandığı yorumu da yapılabilir. "Kanıtlanacak ifadenin temelinde yatan bağlantılara iç görü sağlamak" biçiminde tanımlanabilecek aydınlanma kavramı, matematiksel bir kavramın (ya da önermenin) salt formal gerçekliğinin doğrulanmasının ötesinde; bu kavramın (ya da önermenin) rolünün diğer matematiksel bilgi yapıları bağlamında anlaşılması olarak düşünülebilir. Diğer bir ifade ile matematiksel bir ifadenin, kendisini çevreleyen diğer yapılar ile birlikte oluşturduğu bütünün anlamlılığı ölçüsünde aydınlatıcı olduğu yorumu da yapılabilir. İspatlama sürecindeki karmaşık ilişki ağı dikkate alındığında matematiksel bilginin yapılandırılması sürecinin, hem yeni bir bilginin oluşumuna sebebiyet veren "Aha! Deneyimi", ile hem de bu sürece eşlik eden “Aydınlanma" ile yakından ilişkili olduğu çıkarımı yapılabilir (Kidron ve Dreyfus, 2010).

$\mathrm{Bu}$ aşamaya kadar sunulan kavramsal çerçeveyi de göz önüne alarak ispatlama sürecinde sezgisel ve mantıksal düşünme arasındaki etkileşimi ve bu etkileşimden doğan bilginin yapılandırılması sürecini "bağlamda soyutlama" teorik çerçevesiyle inceleyen Kidron ve Dreyfus (2014), iki profesyonel matematikçinin (K ve L) ispat süreçlerinin mikro-analitik analizleri sonucunda ispat imajı kavramına ulaşmıştır. İspatlama sürecinde önemli bir aşama olarak tanımladıkları ispat imajı kavramını, ispatla ilgili çeşitli bakış açılarından sezgi (Fichbein, 1994), kavramsal anlayış (Sandefur, Mason, Stylianides ve Watson, 2013), semantik ispat oluşturma (Weber ve Alcock, 2009), kavram imajı (Tall ve Vinner, 1981) çerçeveleriyle karşılaştırarak tanıtmışlar ve çift zincirli kavram imajı-kavram tanımı yapısını kullanarak da ispat imajı-formal ispat analojisini oluşturmuşlardır. Yaptıkları diğer çalışmalardan (Kidron ve Dreyfus, 2009, 2010) edindikleri tecrübeleri de değerlendiren yazarlar ispat imajının doğasını aşağıdaki gibi açıklamışlardır:

...sezgisel temsillerin ve mantıksal düşünmenin tamamlayıcı doğası, matematiğin sezgisel ve formal yönleri arasında Fischbein'in (1994) kastettiği anlamda erken seviyede bir senteze izin verir. İspat imajı fikri böyle bir sentezin başlangıcına çok uygundur, çünkü o her ikisi de sezgisel 
olabilecek seçilen önceki yapıların ve mantıksal bağlantıların bir karışımını içerir (Kidron ve Dreyfus, 2014, s. 229).

Buna göre bir iddianın neden doğru olduğunu anlamaya teşebbüs etmiş olan bireyin bir ispat imajına sahip olabileceğini belirten yazarlar, iki bileşenin (Bilişsel Anlayış ve Sezgisel İkna) bireyde bulunması durumunda bu bireyin kesinlikle bir ispat imajına sahip olduğu vurgusunu yapmışlardır. İspat imajını oluşturan iki temel bileşen ve bunların alt boyutları aşağıdaki Tablo 1'de yer almaktadır:

Tablo 1. İspat İmajı ve Bileşenleri

\begin{tabular}{c}
\hline \multicolumn{1}{c}{ ISPAT IMAJI (Kidron ve Drey } \\
\hline Bilişsel Anlayış (Cognitive Understanding) \\
Herhangi bir iddianın doğruluğunu göstermek amacı ile seçilen \\
önceki yapılar ve bu yappları birbirine bağlayan bilişsel sezgiler \\
temelinde aşağıdaki alt bileşenleri içeren bilişsel boyuttur. \\
\hline$B_{1}-$ Kişisel Olma (Being Personal) \\
İmajın, bireyin kişisel çıkarımlarından ve \\
deneyimlerinden izler taşıması ve bunlardan \\
beslenerek gelişim göstermesi. \\
\hline$B_{2}-$ Mantıksal bağlar içerme (Including Logical Links) \\
Seçilen matematiksel yapıların birbirinden yalıtılmış \\
bir çerçeve yerine mantıksal bağlar içerecek şekilde \\
bağlantılı çerçevede ele alınması.
\end{tabular}

\section{Sezgisel İkna (Intuitive Conviction)}

İspat sürecinde bireye gerçekleştirdiği eylemlere ilişkin sezgisel bir ikna sağlayan ve bilişsel anlayış ile karmaşık biçimde bağlantılı olan duyuşsal boyuttur.

Bireyin anlayışını zenginleştiren bilişsel sezgiyi ve mantığı içerir.

\subsection{Problem Durumu}

İspat imajı teorik çerçevesini ortaya koyan yazarlar, orijinal çalışmalarında imajın bileşenlerini teorik bir temel bağlamında tanımlamış ve bunların gözlendiği iki ispat sürecine dair örnekleri paylaşmışlardır. Diğer yandan, ispat imajının olmadığı bir örnek durum incelenmemiş ve dolayısı ile ispat imajı ile formal ispat arasındaki bağlantı derinleştirilmemiştir. Teorik çerçevedeki bu boşluktan hareketle bu çalışmanın problemi "Sonsuz kümeler bağlamında incelendiğinde ispat imajının oluşumunda formal bilginin etkisi nedir?" şeklinde belirlenmiştir. Çalışmanın bağlamı ise Cantor Küme Teorisi ve bu kapsamda ele alınan sonsuz kümeler arası denklik (eşgüçlülük) ilişkileri olarak tercih edilmiştir. Çünkü, tıpkı Kidron ve Dreyfus’un (2014) ispat imajının gelişimine dair açıklamalarında olduğu gibi literatürdeki pek çok çalışma (ör., Kolar ve Čadež, 2012; Pala ve Narl1, 2018a, 2018b; Tsamir, 1999) sonsuzluk kavramının da sezgiselden formele doğru gittikçe karmaşıklaşan düşünsel bir süreci içerdiğine vurgu yapmaktadır. Gelişimsel süreçler arasındaki bu benzerlik dikkate alındığında "sonsuzluk" kavramının ispat imajını incelemek için uygun bir bağlam sağlayabileceği söylenebilir. Bununla birlikte özellikle, ispat için yeterli formal bilginin mevcut olduğu ve olmadığı durumlarda gerçekleştirilen ispat süreçlerinin, ispat imajı teorik çerçevesi 1şı̆̆ında incelenmesi sayesinde bu bileşenin sağladığı katkının belirlenebileceği düşünülmüştür. Özellikle ispat imajını içeren ve içermeyen durumlar arasındaki farkın netleştirilmesi sayesinde öğretimsel uygulamalar için öneriler sunulabilir. Çünkü Selden ve Selden'in (2007) de belirttiği gibi ispat ve ispatlama ile ilgili güçlüklerin farkında olmak bile öğrencilere nasıl yardımcı olunacağ konusunda eğitimcileri daha duyarlı hale getirebilir.

\section{Yöntem}

Bu bölümde çalışmanın deseni, katılımcıları, süreci, veri toplama araçları ve veri çözümleme teknikleri ile ilgili bilgiler sunulmuştur.

\subsection{Araştırma Modeli}

Daha geniş bir doktora tez çalışmasının parçası olan bu çalışma, betimsel türde nitel bir araştırmadır. Nitel araştırma "gözlem, görüşme ve doküman analizi gibi nitel veri toplama tekniklerinin kullanıldığı, algıların ve olayların doğal ortamda gerçekçi ve bütüncül bir biçimde ortaya konmasına yönelik nitel bir sürecin izlendiği araştırma" olarak tanımlanabilir (Yıldırım ve Şimşek, 2013, s. 39). Diğer yandan betimsel araştırmalarda olaylar, objeler ve kavramların ne olduğu betimlenerek açıklanır ve bu sayede değişkenler arasındaki ilişkiler saptanmış olur (Kaptan, 1998). Araştırmada ispatlama süreçlerinin derinlemesine ve çok boyutlu incelenmesi nedeniyle nitel analiz yöntemlerinden durum çalışması (case study) deseni tercih edilmiştir. Bu yaklaşımda bir veya birkaç duruma ilişkin etkenler bütüncül bir yaklaşımla araştırılır ve ilgili durumu nasıl etkiledikleri ve ilgili durumdan 
nasıl etkilendikleri üzerine derinlemesine araştırma yapılır (Yıldırım ve Şimşek, 2013). Sönmez ve Alacapınar'a (2011) göre karmaşık, özel ve ilginç bir olgunun, durumun kendi koşulları içerisinde incelenmesi durum çalışması niteliği taşımaktadır. Bu yöntemde bilinmeyen bir gerçek keşfedilebilir ya da bir durum detaylı bir şekilde tanımlanabilir.

\section{2. Çalıșma Grubu}

Araştırmanın çalışma grubu bir devlet üniversitesinde 2. sınıfa devam eden ilköğretim matematik öğretmen adayları arasından ölçüt örnekleme yöntemi ile seçilen 3 öğretmen adayıdır. Bu sınıf düzeyi, Cantor Küme Teorisi ve özellikle eşgüçlülük ile ilgili temel bilgileri yoğun biçimde içermesi sebebiyle tercih edilmiştir. Çalışma, bir durumu çok boyutlu ve derinlemesine incelemeyi amaçladığından katılımcı sayısı sınırlı tutulmuştur. Ölçüt örnekleme ise problemle ilgili olarak belirlenen niteliklere sahip öğretmen adaylarının seçilmesine olanak sağlaması sebebiyle tercih edilmiştir. Bu örnekleme yöntemindeki temel anlayış, önceden belirlenmiş bir dizi ölçütü karşılayan bütün durumların çalışılmasıdır. Bu noktada çalışmaya dâhil olan katılımcılar için belirlenen ölçüt listesi aşağıda sunulmuştur:

- Düşüncelerini sözlü veya sözsüz olarak ifade etmede güçlük yaşamamak

- Soyut matematik dersindeki akademik başarı

- Araştırmaya katılmak için gönüllü olmak

İspat imajı çerçevesi sosyo-kültürel soyutlama fikrine dayandığından çalışmaya katılan bireylerin düşüncelerini organize ederek karşı tarafa aktarma becerileri dikkate alınmıştır. Yapılan 5 haftalık ders içi gözlemler sayesinde sözlü ve sözsüz dili etkili olarak kullanabilen bireyler belirlenmiştir. Ayrıca katılımcıların kendilerine sunulan ispatları gerçekleştirebilmeleri için "sembolik mantık, kümeler, bağıntılar ve fonksiyonlar" gibi ön öğrenmeleri içeren soyut matematik dersine ilişkin hazırbulunuşluklarının tam olması beklenmiştir. Çünkü Georg Cantor tarafından ortaya konan Küme Teorisi eşgüçlülük, sonsuz kümeler, sayılabilirlik gibi kavramları içerisinde barındırmaktadır. Bu noktada katılımcıların 1. sınıf düzeyindeki akademik başarıları dikkate alınmıştır. Son olarak ilk iki ölçütü sağlayan ve gönüllü olan bireyler içerisinden uzman görüşü doğrultusunda katılımcı bireyler seçilmiştir. $\mathrm{Bu}$ öğretmen adayları Ç, $\mathrm{F}$ ve $\mathrm{N}$ olarak isimlendirilmişlerdir. Katılımcılar çalışma öncesinde ispat temelli derslerden 1. sınıf düzeyinde Genel Matematik ve Soyut Matematik derslerini tamamlamış ve çalışmanın gerçekleştirildiği zaman diliminde Seçmeli I Mantık ve Lineer Cebir I derslerini almaya devam etmişlerdir.

\subsection{Süreç, Veri Toplama ve Çözümleme}

Çalışmaya başlamadan önce, ilk olarak gereken etik izinler ilgili üniversiteye bağlı enstitünün etik kurulundan alınmıştır. Ardından veri toplama sürecine geçilmiştir. Bu süreçte çeşitleme (triangulation) tekniğinden yararlanılmıştır. Büyüköztürk, Kılıç-Çakmak, Akgün, Karadeniz ve Demirel'e göre (2013) çeşitleme; bir araştırmada tek bir yöntem yerine birbirini destekleyen, birbirine entegre olan iki ya da daha çok yöntemin birlikte kullanılmasını sağlayan ve böylece yöntemde zenginleştirmeyi amaçlayan bir uygulamadır. Katılımcıların belirlenmesinin ardından sonsuz kümelerin denkliğine ilişkin düşünme biçimlerinin ve formal/sezgisel yaklaşımlarının belirlenebilmesi için etkinlik temelli mülakat çalışmalarına (Uygulama I-II-III ve IV) geçilmiştir. Uygulama sürecinde pilot uygulamalar hariç her bir katılımcı ile 4 defa bireysel ve 1 defa da sosyo-kültürel etkileşim ortamında grupça olmak üzere toplam 13 ispat etkinliği gerçekleştirilmiştir. Diğer yandan bu çalışmada, formal bilginin ispat imajının inşasındaki rolüne odaklanıldığından paylaşılan veriler ilk iki uygulama (Uygulama I ve Uygulama II) ile sınırlandırılmıştır. Her iki uygulamada da öğretmen adaylarına aşağıdaki soru yöneltilmiş ve onlardan bunu ispatlamaları istenmiştir:

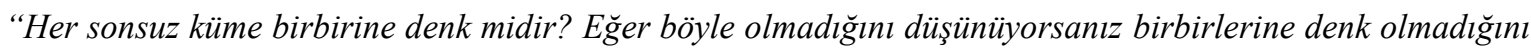
düşündüğ̈̈nüz iki sonsuz küme örneği veriniz. “

Bu soru hem eşgüçlülük kavramına dair temel ilişkileri çok boyutlu olarak içermesi hem de katılımcıların sezgisel yaklaşımlarını kullanmalarına uygun olması nedeni ile iki alan uzmanının görüşleri doğrultusunda tercih edilmiştir. Etkinlik temelli mülakatta ele alınan ispat soruları üst düzey bilişsel becerileri içerdiği ve uzun yanıtlı olduğu için soru sayısı sınırlı tutulmuştur. Uygulamalar, Cantor Küme Teorisi ile ilgili konuları içeren Mantık dersine paralel olarak yürütülmüş ve buna bağlı olarak belirli zaman aralıklarında gerçekleştirilmiştir. İlk uygulama haricinde tüm uygulamalar öncesinde katılımcılara gerekli olan ön bilgiler öğretim üyesi tarafindan ders içerisinde sunulmuştur. Bununla birlikte, ilk uygulamada ise katılımcıların yeterli ön bilgiye sahip olmadıkları durumlarda şekillendirecekleri ispat yaklaşımlarına odaklanıldığından herhangi bir ön bilgi sunulmamıştır. Ayrıca katılımcılar uygulamalarda kendilerine yöneltilen sorular ile daha önce karşılaşmamıştır. Birinci uygulamanın hemen ardından öğretmen adaylarına Cantor Küme Teorisi'nin temel felsefesine ilişkin ilk ders sunulmuştur. Bu derste onların eşgüçlülük kavramına ilişkin temel bilgileri edinmeleri sağlanmış ve iki sonsuz kümenin denkliğinin aralarında tanımlanabilecek bijektif fonksiyonlar ile aşağıdaki tanım doğrultusunda gösterilebileceği açıklanarak örneklendirilmiştir: 


$$
A \sim B \Leftrightarrow\{f \mid f: A \rightarrow B \text {, bijektif }\} \neq \varnothing \text { (Güney ve Özkoç, 2015, s. 418) }
$$

Ayrıca bu aşamanın hemen devamında (ilk uygulamanın ertesi günü) aynı sorunun tekrar ispatlanması istenmiştir. Böylece formal bilgi öncesi ve formal bilgi sonrası bilgi yapılarının / ispat imajlarının ve ispat yaklaşımlarının karşılaş̧ııılabilmesi sağlanmıştır. Tüm bu uygulamalarda soruların cevaplanmasında herhangi bir kısıtlama getirilmeyerek cevaplama serbestliği sağlanmaya çalışılısştır. Katılımcılardan her aşamada düşüncelerini sesli bir şekilde açıklayarak ispatı yapmaları istenmiştir. Gerçekleştirilen tüm süreç iki farklı açıdan kamera ile kayıt altına alınmıştır. Bu kameralardan biri katılımcının kâğıdına odaklanmışken diğeri ise his ve sezgilerini daha iyi analiz edebilmek için yüzüne odaklanmıştır. Diğer yandan her bir ispatın tamamlanmasının ardından katılımcılar ile ispat imajının bileşenlerini değerlendirmeye yönelik yarıyapılandırılmış görüşmeler yapılmıştır. Bu yöntemde araştırmacı hazırlamış olduğu görüşme formundaki soruların yanı sıra ek sorular sorarak derinlemesine bilgi edinebilir. Bu sayede görüşülen kişinin yanıtlarına bağlı olarak görüşme süreci keşiflere açık hale gelebilir. Çalışmada kullanılan görüşme formunda yer alan sorular iki alan uzmanın görüşleri doğrultusunda belirlenmiş ve bunların geçerliliğgi uygulama öncesinde yapılan bir pilot çalışma sayesinde teyit edilmiştir. Buna ek olarak, özellikle ispat imajının his boyutunun değerlendirilmesinde katılımcıların kendilerinden destek alınmıştır. Clore (1992) his kavramını bedensel, bilişsel veya duyuşsal durumlardan bu durumlarla ilgili kullanılabilir bir geri bildirim veya bilgi sağlayan tüm "içsel" işaretler olarak tanımlamaktadır. Bu çalışmanın duyuşsal analizlerinde Clore'un (1992) bu tanımı referans alınmıştır. Dolayısı ile hislerin içsel birer bileşen olduğu dikkate alındığında dışarıdan değerlendirilmesinin oldukça güç olduğu ve bu nedenle katılımcıların hislerinin (örneğin: kuşku, şüphe, mutluluk, kaygı vb.) kendileri tarafindan değerlendirilmesinin daha nesnel olacağı düşünülmüştür. Uygulamalar boyunca her bir ispatın tamamlanmasının ardından, katılımcılara "yüzlerini kaydeden video kaydı" verilmiş ve onlardan his çizelgelerini doldurarak araştırmacıya en kısa süre içerisinde teslim etmeleri istenmiştir. Bu çizelge hangi ispat sürecindeki hangi olayın, hangi his ile eşleştiğini açıklamaları beklenen bir tablodur. Ayrıca uygulamalar başlamadan önce his kavramının tanımı ve bu çizelgenin nasıl doldurulması ile ilgili ön bilgiler de katılımcılara sunulmuştur. Tüm bu tedbirler sayesinde ispat süreçlerinin bilişsel ve duyuşsal boyutları ile ispat imajları açısından derinlemesine analiz edilebilmesine olanak sağlayacak verilerin toplanabileceği düşünülmüştür.

Verilerin toplanmasının ardından çözümleme işlemine geçilmiş̧ir. Transkripsiyon işlemi ile analiz süreci birlikte yürütülmüş ve bu aşamada öğretmen adaylarının ispatlarında gerçekleştirdikleri eylemlerin Kidron ve Dreyfus (2014) tarafından önerilen (bilişsel ve duyuşsal) başlıklara ait kategorilere göre sınıflanmasında betimsel analiz yöntemi kullanılmıştır. Yıldırım ve Şimşek'e (2013) göre betimsel analizde, veriler önceden belirlenen temalara göre özetlenerek yorumlanır ve daha sonra neden-sonuç ilişkileri irdelenerek birtakım sonuçlara ulaşı1ır. Analiz sürecinde ilk olarak her bir ispat kendi içerisinde ayrı ayrı incelenmesinin ardından farklı ispatların bütüncül olarak karşılaştırılması sağlanmıştır. Yapılan kodlama işleminin güvenilir olması için (her ispatın sonunda) alan uzmanından görüş alınmış ve bu doğrultuda gerekli düzeltmeler yapılmıştır. Analizler tamamlandığında katılımcılardan F'nin her iki uygulamada da ispat imajına sahip olmadığı, N'nin her iki uygulamada da ispat imajına sahip olduğu ve Ç'nin ise ilk uygulamada bir ispat imajına sahip olmamasına rağmen ikinci uygulamada (formal bilgiye sahip olduğu durumda) buna sahip olduğu belirlenmiştir. Bu çalışmanın amacı doğrultusunda formal bilginin ispat imajının oluşumuna etkisine odaklanılacă̆ından paylaşılacak veriler Ç'nin olayı ile sınırlı tutulacaktır.

\section{Bulgular}

$\mathrm{Bu}$ bölümde Ç’nin birinci ve ikinci uygulamadaki ispat süreçlerinin analizlerinden elde edilen veriler paylaşılmıştır. Bu aşamada öncelikle ispat süreçlerinden bahsedilmiş ve devamında ise bu ispatların ispat imajının bileşenlerine göre incelenmesi sonucunda elde edilen bulgulara yer verilmiştir. İspat imajının bilişsel boyutunun içerdiği alt başlıkların değerlendirilmesinde bireyin sezgilerinden, söylemlerinden, eylemlerinden, tavırlarından ve diğer tüm epistemik eylemlerinden yararlanılmıştır. İmajın sezgisel ikna boyutu ve özellikle bu kapsamdaki hisler ise Clore'un (1992) yaklaşımı doğrultusunda ele alınmıştır. Bu noktada yapılan değerlendirmelerde öncelikle görüşme verilerinden ve his çizelgelerine verilen yanıtlardan yararlanılmıştır. Ayrıca bazı durumlarda bireylerin ifadeleri ve mimikleri de birlikte değerlendirilerek his boyutu detaylandırılmıştır.

\subsection{Uygulama I - Ç’nin İspat Süreci}

Ç, ispat sürecinin başında soruyu okumasının ardından ilk olarak sonsuzluk kavramı ve sonsuz kümeler üzerine düşünmeye başladı. Bir süre sessiz kaldıktan sonra sonsuz kümeyi "elemanlart sonsuz olan küme" şeklinde tanımladı. Tam sayılar $(\mathbb{Z})$, rasyonel sayılar $(\mathbb{Q})$ ve reel sayılar $(\mathbb{R})$ kümelerinin buna uygun olduğunu belirtti. Ardından, sorulan bu genel soruyu özel bir örnek durumuna indirgeyerek "Yani tam sayllar ile rasyonel sayılar... İkisi de sonsuz küme. Bunlar birbirine denk midir?" sorusunu kendisine yöneltti. Bu aşamada "denklik" kavramı üzerine düşünmeye başladı. Denk kümeleri "elemanları eşit olan kümeler" şeklinde tanımladı ve düşünceli tavırlar içerisinde aşağıdaki ifadeleri yazdı: 


\section{Rasyonel sayibr kimesinin elemalar tan sayibar \\ kímesinin elenonlarindon fazla obbilir}

Şekil 1. Ç’nin $\mathbb{Z}$ ve $\mathbb{Q}$ kümelerine ilişkin ilk düşüncesi

Kendisine böyle bir çıkarıma nasıl ulaştığı sorulduğunda "Her tamsayı bir rasyonel sayıdır, ancak tersi doğru olmayabilir." açıklamasını yaptı. Bununla birlikte neden kesin bir yargı belirtmek yerine "olabilir" ifadesini kullandığı sorulduğunda ise "Sonsuz kümelerin eleman sayılarını sayamıyoruz. Ama ilk bakışta rasyonel sayllar kümesinin elemanları daha fazla görünüyor." cevabını verdi. Bu noktada yaşadığı ikilemin temel sebebini aşağıdaki gibi özetledi:

İlk aklıma gelen rasyonel sayıların elemanlarının daha fazla olduğu... Ama ikisi de sonsuz küme olduğu için elemanlarını sayamayız bence. Bir sonsuzun diğerinden büyük olduğunu söyleyemem. Sonsuzlar arasında karşılaştırma yapmamam ki... Ama ikisinde de sonsuz tane elaman olduğu için bunlar denktir herhâlde.

$\mathrm{Bu}$ noktada, üzerine düşündüğü kümelerin kendisini bir çıkmaza soktuğunu fark ederek reel sayıları $(\mathbb{R})$ da düşünme sürecine dâhil etmeye karar verdi. Ancak benzer bir problemin tekrarlandığını fark ettiğinden bu çıkmazı da aşmayı başaramadı. Bu noktada birbirini kapsayan kümelere dair örneklerin kafa karışıklığı oluşturduğunu ve kendisine bir şey kazandırmadığını ifade etti. Sonrasında bir süre daha düşündü ve kümeler üzerindeki ilişkileri yorumlayabileceği aşağıdaki görsel modeli (sayı doğrusu) oluşturmaya karar verdi:

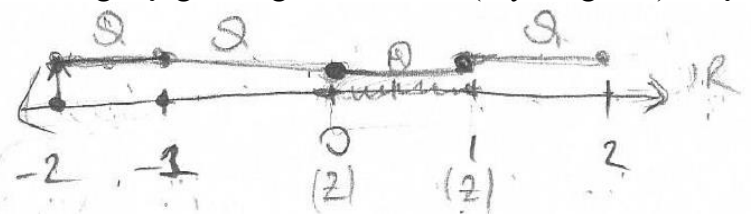

Şekil 2. Ç'nin odaklandığı kümeler ve bunlar arasındaki ilişsileri ifade eden çizimi

Bu model üzerinde özellikle tam sayıların aralarında bulunan boşluklara odaklandı. Bir süre sonra şașkın ve mutlu bir ifade ile "gerçel sayılar ile rasyonel sayıların her ikisinin de sayı doğrusunu kapladı̆̆ıı" ifade etti ve bu nedenle bunların denk olabileceğini belirtti. Bununla birlikte bu aşamada, tam sayılar kümesinin (elemanları arasında boşluk içermesi sebebi ile) bu kümelere denk olamayacağı sonucuna ulaştı. Diğer yandan genel bir sonuca ulaşmak için bu iki örneği yeterli bulmadı ve benzer ilişkiyi farklı sonsuz kümeler açısından tekrar sorgulamaya karar verdi. Bu aşamada aklına gelen ilk kümeler tek sayılar ve çift sayılar oldu. Benzer şekilde, bu kümeleri de bir sayı doğrusu (bkz. Şekil 3) üzerinde gösterdi ve ardışık elemanlar arasındaki ilişkiyi dikkate alarak bunların da denk olması gerektiğine karar verdi.

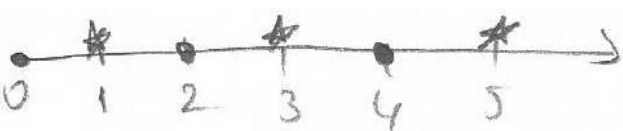

Şekil 3. Ç’nin tek ve çift sayıların denkliğini gösteren çizimi

Diğer yandan, mevcut aşamaya kadar vermiş olduğu örnekler sayesinde sonsuz kümelerin denkliği hakkında kendisini ikna ettiğini belirtmesine karşın üzgün bir tavır ile "denk olmama" durumu için kesin bir sonuca ulaşamadığını söyledi. Tam sayılar $(\mathbb{Z})$ ve rasyonel sayılar $(\mathbb{Q})$ için oluşturduğu şeklin kendisini yanıltıyor olabileceğini belirterek aşağıdaki açıklamayı yaptı:

Görsel üzerinden bakınca bunların (tek ve çift sayıları kastediyor) birbirine eşit olduğunu düşünüyorum. Ama tam sayılar ile rasyonel sayıların eşit olmadığını düşünüyorum. (Kararsız bir ses tonu ile) Şekil bence beni aldatıyor. Çünkü sözel olarak ifade ettiğimizde sonsuz eleman sonsuz elemana eşittir.

Açıklamanın devamında bir süre daha sessiz kaldı ve özellikle ilk çizdiği sayı doğrusuna odaklanarak düşünmeye devam etti. Bir süre sonra, sayı doğrusundaki tam sayılar arasında kalan boşlukları kaleminin ucu ile tekrar işaret ederek aşağıdaki açıklamayı yaptı:

Rasyonel sayıların içinde, tam sayı olmayan sonsuz eleman var. Biz bunları rasyonel sayılardan çıkardığımızda geriye sadece tam sayılar kalır. Bu, sonsuzdan sonsuzu çıkarmaktır ve belirsizlik oluşur.

Bu aşamada $\infty-\infty=\infty$ sorusuna bir yanıt bulma çabasına girişti ancak birkaç basit denemenin ardından pes etti. İspata devam edememesinin gerekçesi olarak özellikle " $\infty-\infty$ " durumunun matematiksel anlamı üzerine (bunun neden bir belirsizlik olduğu hakkında) hiç düşünmemiş olmasını gösterdi. Dolayısı ile ispata devam edebilecek yeterli bilgisi olmadığını söyledi ve aşağıdaki ifadeleri yazarak bu sürece bir son verdi. 


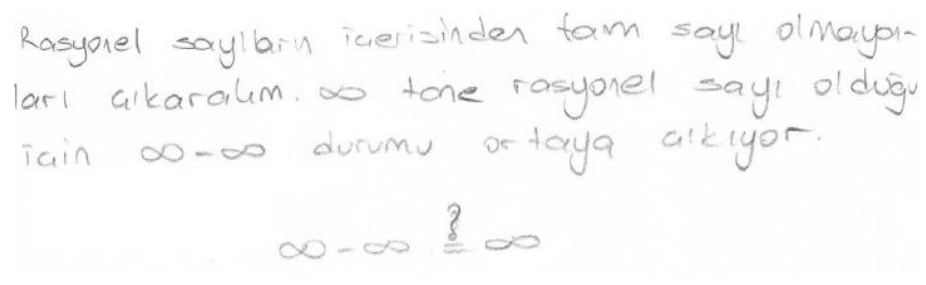

Şekil 4. Ç’nin $\mathbb{Z}$ ve $\mathbb{Q}$ kümeleri bağlamında belirlediği $\infty-\infty \stackrel{?}{=} \infty$ belirsizlik durumu

\subsection{Uygulama I - Ç’nin İspat İmajının Bileşenlere Göre Değerlendirilmesi}

İlk uygulama öncesi katılımcılara Cantor tarafından önerilen eşgüçlülük kavramı hakkında herhangi bir ön bilgi sunulmamış ve onların yetersiz hazırbulunuşluk durumunda bir ispat imajı oluşturup oluşturamayacaklarının incelenmesi hedeflenmiştir. Diğer yandan yapılan analizler sonucunda Ç'nin bu uygulamada bir ispat imajına sahip olmadığı belirlenmiştir. Alt bileşenler bağlamında elde edilen sonuçlar aşağıda sunulmuştur.

\subsubsection{B $B_{1}-$ Kişisel Olma}

İspat süreci incelendiğinde bu sürecin, Ç’nin zihnindeki özgün bir düşünme biçimi doğrultusunda gelişim gösterdiği yorumu yapılabilir. Diğer biri ifade ile o, herhangi bir dış kaynaktan (öğretmen, kitap vb.) edindiği yaklaşımı doğrudan taklit etmek yerine kendi bireysel fikirleri doğrultusunda ispatlama girişiminde bulunmuştur. İspatın her bir aşamasında ortaya attığı iddiaların doğruluğuna ilişkin kendi argümanlarını oluşturmaya çalışmıştır. Dolayısı ile ortaya çıkan ürünün, Ç’nin kendi bilişsel çabalarının bir sonucu olarak inşa edildiği ve bu nedenle onun imajının kişisel anlayış karakteristiğine sahip olduğu sonucuna ulaşılabilir. Ayrıca yapılan görüş̧mede benzer bir ispatı daha önce görmediğini açıkça ifade etmesi de bu karakteristiğe dair göstergelerden biri olarak değerlendirilebilir.

Ç, anlayışını oluştururken, "her sonsuz küme" için yöneltilen genel bir sorunun özel örnekleri üzerinde düşünerek kapsamlı bir çıkarıma ulaşmaya çabalamıştır. Bu nedenle oluşturulan örneklerin, onun anlayışının şekillenmesinde önemli katkısı olduğu söylenebilir. Söz konusu örnekler sayesinde Ç, çeşitli denemeler yapabilmiş ve böylece bazı sonsuz kümelerin denk olabileceğini belirlemiştir. Buna karşın, büyük oranda bilgi düzeyinden kaynaklanan yetersizlikler nedeni ile bazı sorulara yanıt verememiş ya da sezgisel yanıtlar içeren yüzeysel açıklamalar getirebilmiştir. Bu nedenle, bir anlayış geliştirebilmesine rağmen bunu derinleştirmede zorluklar yaşadığı ve çıkmaza giren ispatını bir sonuca taşıyamadığı yorumu da yapıllabilir.

\subsubsection{B2- Mantıksal Bağlar İçerme}

İspat süreci incelendiğinde Ç’nin genel olarak formal matematiğin kendisi ile başlamayan ve informel bileşenlerden yola çıkan bir ispatlama aktivitesi gerçekleştirdiği söylenebilir. Bu süreçte o, kişisel anlayış1 doğrultusunda pek çok matematiksel yapıyı tanıyarak (R-) seçmiş ve bunları ispat sürecinde ilerleyebilmek için pek çok noktada kullanmıştır (B-). Bu karakteristiğe ispat içerisinde pek çok farklı noktada rastlanmaktadır. Örneğin Ç’nin tam sayılar kümesinin elamanları ile rasyonel sayılar kümesinin elemanları arasında kurduğu alt küme ilişkisi bu karakteristiğe bir örnek olarak yorumlanabilir. Diğer yandan Cantor Küme Teorisi'ne ilişkin bilgi düzeyine ilişkin yetersizlikten dolayı beklenen formal ilişkilerin pek çok noktada kuramadığı belirlenmiştir. Ç, sonlu kümeler için geçerli olan "eleman sayıları eşit olan kümeler denktir" tanımından öteye geçememiş ve Cantor tarafından önerilen birebir-örten (bijektif) eşleme fikrini kullanamamıştır. Dahası süreçler içerisinde sonsuzluk kavramını temel alan pek çok hatalı ve yetersiz ilişkinin varlığından da söz edilebilir. Örneğin Ç’nin ispatının son aşamasında ortaya çıkan " $\infty$ - $\infty$ " durumunu denklik bağlamında anlamlandıramaması bunlardan biri olarak gösterilebilir. Buna ek olarak onun kurduğu ilişkilerde formal düşünme biçimi kadar sezgilerinin de etkisi altında kaldığ 1 da söylenebilir. Örneğin, rasyonel sayılar ile tam sayılar kümelerini karşılaştırırken tam sayılar arasındaki boşlukları dikkate alarak bu iki kümenin denk olamayacağını ifade etmesi, sezgisel yaklaşımlara dair örnekler arasında değerlendirilebilir. Ayrıca, Ç’nin sezgilerini doğrulayabilecek ya da yanlışlayabilecek yeterli matematiksel bilgiye sahip olmamasının onu ispat süreci içerisinde bir çıkmaza doğru sürüklediği de söylenebilir. Örneğin o, görsel sezgilerini dikkate aldığında tek ve çift sayıları "denk" sonsuz kümeler olarak nitelendirmesine rağmen rasyonel sayllar ve tam sayıları ise "denk olmayan" sonsuz kümeler olarak nitelendirmiş̧ir. Bu nedenle onun "Her sonsuz küme denktir." biçimindeki sezgisinin bazen güçlenip bazen de zayıflayarak kararsız bir dalgalanma gösterdiği yorumu yapılabilir. Bu durum, onun ispatlama aktivitesini bir sonuca ulaştıramamasının önemli bir sebebi olarak değerlendirilebilir.

\subsubsection{B-Dinamik Olma}

Ç, ispat sürecinde her sonsuz kümenin denk olması gerektiğine dair bir sezgiyi benimsemiş ve bunun doğruluğunu farklı örnekler (tek sayılar-çift sayılar, rasyonel sayılar-tam sayılar) üzerinde test etmiştir. Bu noktada onun, ispatını daha az sayıda bileşen (temel kavramlar, temel aksiyomlar vb.) içeren basit bir 
bağlantılardan daha çok sayıda bileşeni içeren (ilişki ağları, hisler vb.) karmaşık bir düzeye taşıyabildiği görülmüştür. Ancak ihtiyaç duyduğu noktaları açıklayabilecek yeterli formal bilgi düzeyine sahip olmaması, onu sezgisel varsayımların yönlendirmesine iten bir ispat sürecine doğru sürüklemiştir. Diğer bir ifade ile matematiksel bilgiler arasında olması beklenen" gerekçelendirme" boyutu beklenen düzeye ulaşamamıştır. Bu ise ispat sürecinin aşamaları arasındaki hiyerarşik bağlantıları zayıflatmış ve kapsamlı bir ispat yönteminin oluşmasını engellemiştir. Dolayısı ile Ç'nin kısmen tutarlı bağlantılar içeren ve ayrık yapılar tarafından oluşan statik bir imaj elde ettiği söylenebilir. İspat sürecinin sonundaki görüşmede yapmış olduğu "Çelişki bulmak için gittim ama olmadı. Bazen aklım başka noktalarda da gitti ama bir sonuç bulamadım.” açıklaması onun sürecinde sarmal (dinamik) bir gelişim yerine farklı kollara ayrılan -parçalı- bir ispat süreci deneyimlediğinin göstergesi olarak değerlendirilebilir.

\subsubsection{B4-Bütünlük}

Ç’nin ispat sürecinde tam bir dinamik gelişim olmaması nedeni ile imajın bir bütünlük taşımadığı ve bu nedenle bütüncül bir imaja sahip olamadığı söylenebilir. Dahası, onun birbirinden ayrı imaj parçalarına sahip olduğu yorumu da yapılabilir. Bu parçalı imaj nedeni ile Ç’nin ispat sürecinde gerçekleştirdiği aşamaları bir bütün olarak zihninde taşıyamadığı ve önceki aşamalarda ulaştığı sonuçları birlikte kullanması gerektiği noktalarda çelişkiler yaşadığı yorumu da yapılabilir. Örneğin o, gerçekleştirdiği eylemlerin sonucunda tek sayılar ile çift sayıların birbirine denk olabileceğini (sayı doğrusu üzerinde) görmüş ancak tam sayılar ve rasyonel sayılar açısından kesin bir yargıya ulaşamamıştır. Dahası sonsuz kümelerin denkliği açısından biri "alt küme ilişkisine" dayanan ve diğeri de "sonsuzluğun tek olabileceği sezgisine" dayanan iki farklı yorum getirmiş ve bunlardan herhangi birini yanlışlayabilen delillere ulaşamadığından sürece son vermeyi tercih etmiştir. Bu bağlamda özellikle ispat sürecinin bir sonuca ulaşamaması ve "tamamlanmamış" olarak bırakılması bu karakteristiğin eksikliğine dair önemli göstergeler arasında değerlendirilmiştir. Bununla birlikte söz konusu karakteristiğin eksikliğinin, Ç’nin olayında ilham verici anları (içgörü ve aydınlanma) deneyimleyememesinin önemli bir sebebi olduğu söylenebilir. Çünkü bu karakteristiğin eksikliği sebebi ile ilham verici anlarının oluşumuna olanak sağlayan; "sürece kapsamlı bir bakış”, “önceki aşamalarla bağlantılar kurmak" ve "sonraki aşamaları ön görebilmek” gibi temel bileşenler sağlanamamıştır.

\subsubsection{Sezgisel İkna}

Ç’nin ispat sürecinde yaşadığı bilişsel dalgalanmaya bağlı olarak farkı duyuşsal deneyimler yaşadığı söylenebilir. Onun özellikle başlangıçta sonsuz kümelerin denk olması gerektiğine dair bir sezgiyi benimsediği ancak süreç içerisinde bunu sorguladığı noktalarda istediği sonuçlara ulaşamadığ için kendisini ikna edemediği sonucuna ulaşılabilir. Bununla birlikte düşüncelerini doğrulamaya çalıştığı noktalarda yer yer olumlu his deneyimleri yaşadığı hem yapılan görüşmedeki açıklamalarında hem de his çizelgesi üzerine aldığı notlarda görülebilmektedir. Örneğin çizdiği sayı doğrusu üzerinde "tek ve çift sayıların denk olması gerektiğini" gördüğünde hem doğru iz üstünde olduğunu hem de kümelerin denkliğine dair sezgisinde haklı olduğunu ifade etmiştir. Bununla birlikte benzer şekil üzerinde tam sayılar ile rasyonel sayıları kıyasladığında (iki tam sayı arasında sonsuz rasyonel sayı olduğunu dikkate alarak) bu kümelerin denk olmaması gerektiğini fark etmiş ve bu durumun "sonsuz kümeler denktir" sezgisi ile çeliştiğini görerek "şüphe hissine" kapıldığını his çizelgesine not etmiştir. Diğer yandan yaşadığı çelişkiyi çözümleyebilecek yeterli bilgiye sahip olmadığını ifade ederek ispat sürecini sonlandırmıştır.

\subsection{Uygulama II - Ç'nin İspat Süreci}

Ç, ikinci uygulamanın başında soruyu tebessüm ile okudu ve ardından uygulamadan hemen önceki derste öğrendiklerini aşağıdaki gibi ifade etti:

Denklik, eleman sayılarının eşit olmasıydı ama eğer iki küme arasında birebir-örten bir fonksiyon varsa birbirine denk olmuş oluyor. Derste bununla ilgili örnekler verdik.

Bu noktada sonlu kümeler için geçerli olan denklik tanımının ( $A \equiv B \Leftrightarrow s(A)=s(B))$ sonsuz kümeler için uygulanabilir olmadığını ifade ederek derste görmüş olduğu bijektif eşlemelerden aşağıdaki gibi örnekler verdi:

$$
\begin{aligned}
f(x)=x & \rightarrow x \text { asal } \\
1 & \rightarrow 2 \\
2 & \rightarrow 3 \\
3 & \rightarrow 5 \\
\mid N & \sim \mathbb{P}
\end{aligned}
$$$$
\begin{aligned}
& 1 \rightarrow 0 \\
& 2 \rightarrow 1 \\
& 3 \rightarrow-1 \\
& 4 \rightarrow 2 \\
& \frac{x}{2} \times \text { aitse } \\
& \frac{1-x}{2} \times \text { tetse }
\end{aligned}
$$$$
I N \sim Z
$$

Şekil 5. Ç'nin derste görmüş olduğu $\mathbb{P} \sim \mathbb{N}$ ve $\mathbb{N} \sim \mathbb{Z}$ için oluşturduğu örnek eşlemeler 
Bu örneklerin ardından soruya tekrar odaklandı ve vermiş olduğu örneklerin "her sonsuz küme" için yeterli bir yanıt oluşturmadığını fark ederek "bilmediğim sonsuz kümeler de olabilir ve onlar birbirine denk olmayabilir" açıklamasında bulundu. Dahası, uygun bir örnek bulabildiği takdirde soruya cevap verebileceğini söyleyerek bir önceki uygulamada kesin bir yanıt bulamadığ $\mathbb{Q}^{\sim} \mathbb{R}$ sorusu üzerine tekrar düşünmeye başladı. İlk olarak, bir önceki uygulamadaki yaklaşımını "İkisini de sayı doğrusu üzerinde gösterdim. Bir eşleme yaptım. Eleman sayıları eşittir dedim." şeklinde özetledi ve bu defa bijektif bir eşlemeye odaklanacağını ifade etti. İki küme arasında bazı fonksiyonlar $\left(f(x)=x\right.$ ve $f(x)=x^{2}$ gibi) oluşturmayı denese de bunların bijektif olma koşullarını sağlamadığını dikkate alarak denklik hakkında kesin bir yargı belirtmekten kaçındı. Bu noktada, seçtiği kümeler üzerinde düşünmekte zorlandığını belirterek örneğini değiştirdi. Bir sonraki aşamada $\mathbb{Q} \stackrel{\text { ? }}{\sim} \mathbb{Z}$ sorusuna yanıt aramaya karar verdi. İlk olarak rasyonel sayılar ile tam sayıların elemanları üzerine düşündü ve kesirli bir fonksiyon yazması gerektiğini ifade ederek "f: $\mathbb{Q} \rightarrow \mathbb{Z}, \mathrm{f}(\mathrm{x})=\frac{1}{x}$ " eşlemesini tanımladı. Bu noktada, kısa bir süre düşündükten sonra bunun geçerli bir fonksiyon olamayacağını söyledi. Bunun nedeni sorulduğunda "Mesela $1 / 2$ 'yi almış olsam 2'ye gidecek. Ama $\frac{2}{3}$ almış olsam $\frac{3}{2}$ 'ye gidecek ve o da rasyonel." cevabını verdi. Rasyonel sayılar ile tam sayılar arasındaki kıyaslama için "rasyonel sayılarda daha çok eleman varmış gibi geliyor" açıklamasını yaptı. Sonrasında bir süre sessiz kalarak ispatın başından itibaren vermiş olduğu örnekleri sırasıyla inceledi ve "alt küme" ilişkisinin kümelerin denkliği açısından bir sorun yaratmadığını belirledi. Bu aşamada (önceki uygulamada olduğu gibi) şekil çizmenin işe yarayabileceğini umarak aşağıdaki sayı doğrusunu çizdi ve ardından altta sunulan açıklamayı yaptı:

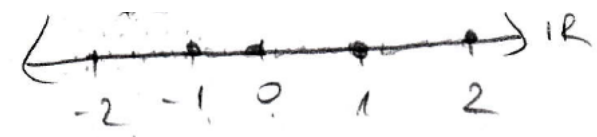

Şekil 6. Ç’nin $\mathbb{Q}$ ve $\mathbb{Z}$ kümeleri üzerine düşünmek için oluşturduğu sayı doğrusu

(İç çekerek) Ama... Rasyonel sayılar sonsuz tane. Buradaki (-2 ile -1 arasındaki bir noktayı kastediyor) bir sayıyı buna (-2 sayısını kastediyor) eşledim diyelim. Başka birini de bunla ( -1 sayısını kastediyor) eşledim. Diyorum ki aradaki sayılar (-2 ile -1 arasındaki diğer rasyonel sayılar) kalıyor. Onu eşleyecek tam sayı bulamayabiliriz. Şekle baktığımız zaman...

Devamında, şekil çizme yaklaşımını derinleştirerek iki küme arasında tanımlanabilecek bir fonksiyon grafiğinin nasıl olabileceği üzerinde düşünmeye başladı. Bir koordinat ekseni oluştururken sesli biçimde düşündü ve altta sunulan açıklamaları yaptı:

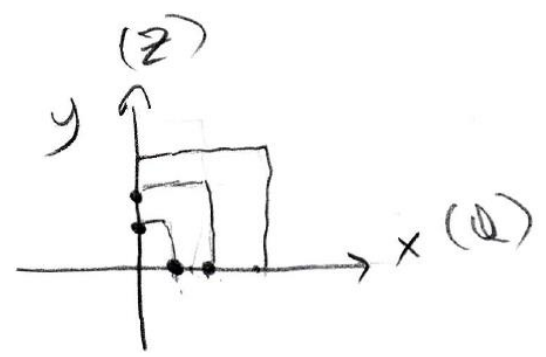

Şekil 7. Ç’nin $\mathbb{Q}$ ve $\mathbb{Z}$ kümeleri arasında tanımlanabilecek bir fonksiyon için oluşturduğu grafik

Burada ( $\mathrm{x}$ - ekseni üzerindeki bir noktayı işaretliyor) almış olsam, buraya (y- ekseni üzerindeki bir noktayı işaretliyor) götürecek. Götürecek yani... (Bir şey fark ederek) Ama buralarda (x- ekseninde yer alan noktaları göstererek) da iki rasyonel sayı arasında belki bir rasyonel sayı var (?).

Eksenleri incelerken "iki tam sayı arasında başka bir tam sayı olmadığını” bilmesine rağmen rasyonel sayılar için böyle bir kısıtlama getiremeyeceğini fark etti. Bununla birlikte, bu varsayımı matematiksel olarak doğrulamadan ilerlemek istemedi. Bu noktada, ardışı tam sayılara benzer şekilde ardışı rasyonel sayılar olup olamayacağını düşünmeye başladı ve (aynı birim kesirle ardışık olarak oluşturulan) $\frac{1}{3}$ ile $\frac{2}{3}$ sayılarını örnek olarak seçti. Bir süre düşündükten sonra, denk kesir kavramını da kullanarak seçtiği sayılar arasında farklı rasyonel sayılar yazabileceğini aşağıdaki gibi gösterdi ve böylece sezgisinde yanılmadığını anladı: 


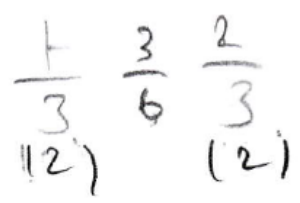

Şekil 8. Ç’nin iki rasyonel sayı arasında belirlediği diğer rasyonel sayı

Diğer yandan bu sonuç, onun $\mathbb{Q}$ ve $\mathbb{Z}$ arasında oluşturduğu grafiğin aslında bir fonksiyon olmadığını anlamasına da yardımcı oldu ve bu sebeple hayal kırıklığına uğramış bir ses tonu ile "Fonksiyon çizme de olmadı, sayı doğrusu da olmuyor. Fonksiyon da yazamıyorum. Belki de denk değil." açıklamasını yaptı. Bu noktadan sonra kümelerin denkliği yerine denk olmaması üzerine düşüneceğini belirterek $\mathbb{R}$ ve $\mathbb{N}$ kümeleri üzerine odaklandı. Neden bu kümeleri seçtiği sorulduğunda aşağıdaki açıklamayı yaptı:

Çünkü bu $(\mathbb{R})$ en büyük, diğeri $(\mathbb{N})$ en küçük... Reel sayılar kümesi, doğal sayıları kapsıyor. Kapsayanların benim bildiğim en büyüğü.

Bir süre kümelerin elemanları üzerinde düşündükten sonra bunları bütüncül olarak görebileceği bir say1 doğrusu çizdi. Sonrasında birebir-örten bir eşlemenin nasıl olabileceğini zihninde canlandırmaya çalışırken altta sunulan açıklamaları yaptı:

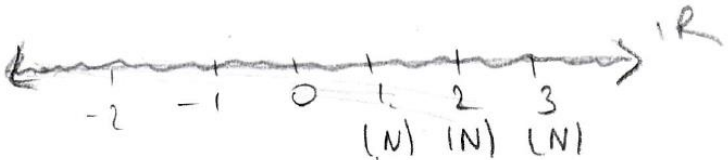

Şekil 9. Ç’nin $\mathbb{R}$ ve $\mathbb{N}$ kümelerini bütüncül olarak görmek için çizdiği sayı doğrusu

Şurada (sayı doğrusunun sol tarafında, -2 elemanından sonraki aralığın en uç noktasını işaret ederek) uç noktadaki bir reel sayıy 1 ile eşleyebilirim. Onun yanındakini 2 ile eşlerim. Böyle kaydıra kaydıra götürebilirim. Zaten sonsuz tane doğal sayı var.

Ancak sözel olarak dahi ifade etmekte zorlandığı bu eşlemeyi kurallı bir fonksiyon haline getirmeye çalıştığında oldukça zorlandığı görüldü. Bir süre düşündükten sonra karamsar bir ifade ile fonksiyon yazamayacağını belirtti. Bu karamsarlığının sebebi sorulduğunda “...benim burada birebir örten olmasına bakmam lazım aslında ama bakamıyorum. Çünkü bir fonksiyon dahi tanımlayamıyorum.” açıklamasını yaparak yaşadığı güçlüğü özetledi. Doğal sayıların elemanlarını teker teker yazabildiğini ancak bunu gerçel sayılar için başaramadığını belirtti ve ardından iki kümeden seçtiği elemanları aşağıdaki gibi daha açık biçimde yazarak bunlar üzerine düşünmeye başladı:

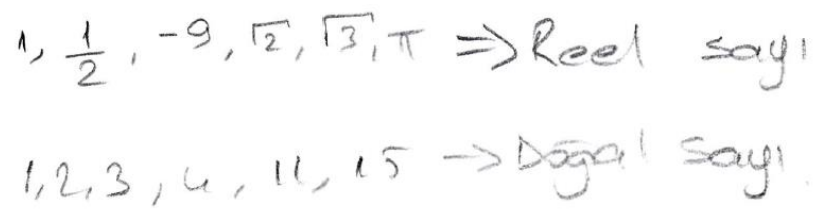

Şekil 10. Ç’nin $\mathbb{R}$ ve $\mathbb{N}$ kümeleri için yazdığı bazı elemanlar

Bu noktada, kümelerin elemanları arasındaki ilişkileri açıkça görebileceği görsel bir eşleme oluşturmaya karar verdi. Doğal sayılardan ardışık elemanları ve gerçel sayılardan bazılarını seçerek aşağıdaki eşlemeyi yaptı:

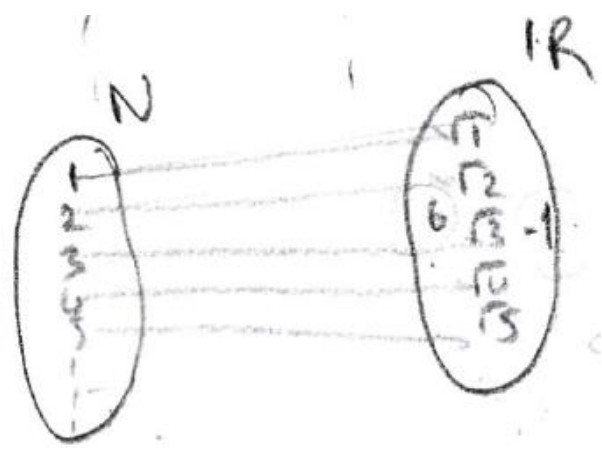

Şekil 11. Ç'nin $\mathbb{R}$ ve $\mathbb{N}$ kümeleri arasında tanımladığı (görsel) eşleme

Bu noktada, her doğal sayıyı kareköküne bağlayan okları işaretleyerek bu eşlemenin $\mathrm{f}(\mathrm{x})=\sqrt{x}$ biçiminde kurallaştırılabileceğini belirtti. Dahası bunun birebir olmasına rağmen bu hali ile örten olamayacağını da 
söyledi. Bu görüşünü detaylandırması istendiğinde, diyagramda (sağ tarafta) yer alan ve hiçbir doğal sayı ile eşleşmeyen "-1" ve " 6 " elemanlarını işaret ederek bunların açıkta kaldığını vurguladı. Diğer yandan, bu noktada fonksiyonun kuralının değişmesi durumunda açıkta kalan elemanların eşlemeye dâhil edip edilemeyeceğini sorgulamaya başladığı görüldü. Gerçel sayılar kümesinin, irrasyonel sayılar dışında, tam sayılar ve rasyonel sayılar gibi diğer elemanları da içereceğini dikkate alan farklı zihinsel denemelerde bulundu. Bir süre sonra, boşta kalan tam sayıların eşlemeye dâhil edilmesi durumunda dahi reel sayılar içerisindeki farklı elemanların açıkta kalmaya devam edeceğini söyleyerek aşağıdaki açıklamayı yaptı:

Benim hissettiğim bu. Denk olmayabilirler. (Gülümser) Çünkü olmuyor. Reel sayılarda bir kısmı alınca diğer kısım boşta kalıyor. Ben ne kural yazarsam yazayım, bence böyle olacak. Bir kısım yine boşta kalacak. Birebirliği sağlıyor onda bir sıkıntı yok ama örtenliği sağlamayacak.

Bu noktada bir kez daha genel bir yargıya ulaşmaktan kaçındı ve dahası, reel sayılar kümesi yerine sadece irrasyonel sayılar kümesini dikkate alarak $\mathbb{I} \stackrel{?}{\sim} \mathbb{N}$ sorusu üzerine düşünmeye devam etti. Bir önceki duruma benzer olarak, elemanlar arasında tanımladığı açık bir eşlemeyi aşağıdaki gibi oluşturdu:

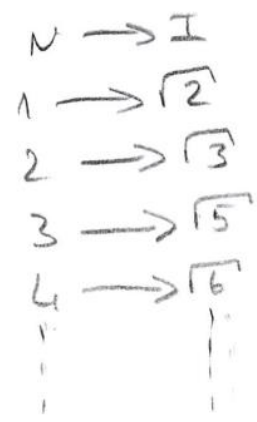

Şekil 12. Ç’nin $\mathbb{N}$ ve II kümeleri arasında oluşturduğu (görsel) eşleme

$\mathrm{Bu}$ eşlemeyi oluşturmasının hemen ardından tereddütsüz bir şekilde bunun da örten olamayacağını, çünkü bu sefer de “ $\sqrt{2}+2$ ", " $\pi$ ” ve "e" gibi elemanların açıkta kalacağını söyledi. Bu durumun $\mathbb{N} \sim \mathbb{R}$ sorusu ile büyük benzerlik gösterdiğini fark etmesinin hemen ardından doğal sayıların, gerçel sayılara asla denk olamayacağını aşağıdaki gibi kesin bir yargı ile açıkladı:

Ben sabaha kadar uğraşsam da yazamam. Örtenliği sağlamayacak... İlla bir boşluk kalıyor irrasyonel sayılarda. Mesela “ $\sqrt{2}+2$ ” bir irrasyonel sayı, onu eşleyecek doğal sayı yok. Ki irrasyonel sayılarda açıkta eleman kalıyorsa, reel sayılarda hayli hayli kalır. Bence o yüzden denk değildir.

Ç, bu açıklamanın ardından birbirine denk olmayan sonsuz kümeler olabileceği sonucuna ulaştı ve aşağıdaki açıklamayı mutlu bir yüz ifadesi ile yazarak ispat sürecini tamamladı.

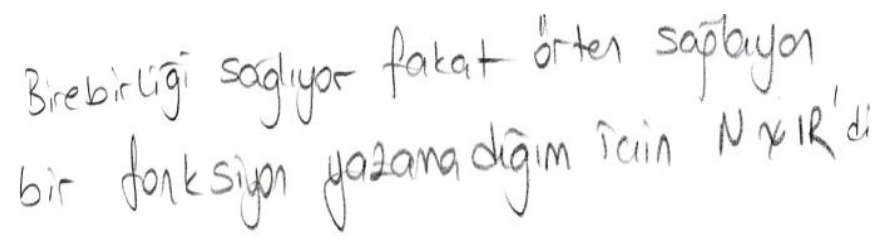

Şekil 13. Ç’nin ispat sürecinin sonunda ulaştığı sonuç

\subsection{Uygulama II - Ç’nin İspat İmajının Bileşenlere Göre Değerlendirilmesi}

İkinci uygulama, ilk uygulamanın üzerinden 24 saat dahi geçmeden gerçekleştirilmiştir. Bu uygulama öncesinde, katılımcılara aynı sorunun tekrar yöneltileceğine dair hiçbir ipucu verilmemiştir. Ayrıca, uygulamalar arasında geçen sürede bir araştırma yapılmaması istenmiş ve onların da bu doğrultuda hareket ettikleri varsayılmıştır. Bununla birlikte ikinci uygulama öncesinde katılımcılara öğretim elemanı tarafından eşgüçlülük fikrinin temel felsefesini içeren bir ders sunulmuştur. Dolayısı ile ikinci uygulamanın amacı katılımcıların Cantor Küme Teorisi'ne dair formal bilgiye sahip oldukları durumda oluşturacakları (veya oluşturamayacakları) ispat imajlarının bileşenleri incelenmesidir. Böylece "formal bilginin” ispat imajı teorik çerçevesi bağlamındaki rolünün detaylandırılabileceği düşünülmüştür. Diğer yandan yapılan analizler sonucunda Ç’nin bu uygulamada bir ispat imajına sahip olduğu belirlenmiştir. Alt bileşenler bağlamında elde edilen sonuçlar aşağıda sunulmuştur.

\subsection{1. $B_{1}-$ Kişisel Olma}

Ç’nin ispat süreci incelendiğinde, onun derste sunulan örnekleri tekrar ederek bunları bir çıkış noktası olarak belirlediği söylenebilir. Bununla birlikte, o derste öğrenmiş olduğu temel bilgilerden çıkardığı sonuçları 
kullanarak kendi özgün yaklaşımını oluşturabilmiştir. Bu özgün yaklaşımın en önemli göstergelerinden biri, onun farklı örnekler üzerinde düşünme konusundaki istekliliğidir. Ç'nin ispat sürecinde sorguladığı sorular aşağıdaki tabloda özetlenmiştir:

Tablo 2: Ç’nin Uygulama II'de Yanıt Aradığı Soruların Dağılımı

\begin{tabular}{c|c}
\hline \multicolumn{2}{c}{ Ç'nin İspat Boyunca Yanıt Aradı̆̆ Sorular } \\
\hline Derste Yanıtlanmış Olanlar & Derste Yanıtlanmamıs Olanlar \\
\hline $\mathbb{N} \stackrel{?}{\sim} \mathbb{P}$ & $\mathbb{R} \sim \mathbb{Q}$ \\
$\mathbb{N} \stackrel{?}{\sim} \mathbb{Z}$ & $\mathbb{Q} \sim \mathbb{Z}$ \\
& $\mathbb{R} \sim \mathbb{N}$ \\
& $? ? ? \mathbb{N}$ \\
\hline
\end{tabular}

Farklı sonsuz kümeleri kullanma tercihinin "her sonsuz küme" için geçerli olabilecek bir genellemeye ulaşma çabasından kaynaklandığı söylenebilir. Sunulan tablodan hareketle, Ç’nin sonsuz kümelerin denkliğine dair ilişkileri derste görmüş olduğu örnekler ile sınırlamadığı ve bunların dışına çıkabildiği sonucuna ulaşılabilir. Dahası, onun çok sayıda ve farklı örnek üzerine düşünmesi sayesinde farklı yaklaşımları deneyimleyerek bakış açısını genişletebildiği ve böylece gittikçe formalleşen bir çerçevede bunları dişarı aktarabildiği çıkarımları yapılabilir.

\subsection{2. $B_{2}-$ Mantıksal Bağlar İçerme}

İspat süreci bütünsel olarak incelendiğinde Ç’nin pek çok farklı noktada anlayışını derinleştirmek için çeşitli matematiksel yapıları seçtiği (R-) ve bunlar arasında büyük bölümü mantıksal gerekçelendirmeye dayanan bağlantılar kurarak bunları kullandığı (B-) yorumu yapılabilir. Ayrıca tanınan ve kullanılan bu yapılar incelendiğinde Ç’nin ikinci uygulama öncesinde sunulan dersten oldukça etkilenmiş olduğu yorumu da yapabilir. İlk uygulamada ele alınmayan "fonksiyon" kavramının ikinci uygulamada etkin biçimde kullanılmış olması bu duruma dair belirgin bir gösterge olarak değerlendirilebilir. Ç, bu kavramı çoğunlukla tek başına ele almamış ve birebirlik-örtenlik özellikleri ile ilişkilendirerek kullanmıştır (B-). Bununla birlikte onun ilk uygulama ile kıyaslandığında büyük oranda formal matematiksel araçları temel alan bir yaklaşımı benimsediği de söylenebilir. Örneğin $\mathbb{Q}$ ve $\mathbb{R}$ kümeleri arasındaki ilişkiyi incelerken " $f: \mathbb{Q} \rightarrow \mathbb{R}, f(x)=x$ " fonksiyonunu tanımlamasının ardından yapmış olduğu aşağıdaki açıklama formal yaklaşıma dair örnekler arasında değerlendirilebilir:

Ama ben buraya aslında... $\mathrm{f}(\mathrm{x})=\mathrm{x}$ yazmış olsam birebir olur ama örten olmuş olmaz. Çünkü reel sayılarda elemanlar boşta kalacak. Bu örnek olmadı. Reel sayılar... Doğal sayıları kapsıyor, tam sayıları kapsıyor. Rasyonel sayılar var. İrrasyonel de var. Her türlü reel sayılarda boşta eleman kalıyor.

$\mathrm{Bu}$ açıklamada Ç, formal ilişkilerden yararlanmış ve fonksiyonun tanım kümesi ile görüntü kümesi arasında birebir-örtenlik bağlamında incelemelerde bulunmuştur. Öncelikle kümelerin kendisi üzerine düşünmüş ve sonra da " $\mathrm{f}(\mathrm{x})=\mathrm{x}$ " kuralıyla yazılan fonksiyonun $\mathbb{Q} \rightarrow \mathbb{R}$ şeklinde tanımlanması durumunda, gerçel sayılarda açıkta kalacak elemanlar olacağından hareketle bu eşlemenin örten olamayacağı çıkarımını ifade etmiştir. Benzer formal çıkarımların, Ç’nin ispata ulaşmasında önemli katkıları olduğu söylenebilir. Çünkü o, seçtiği (R-) kavramlar arasında varsayımlarda bulunmaktan kaçınmış ve bu sayede gerekçelendirilmiş bir ilişki ağı elde edebilmiştir. İspat sürecinin sonunda yapılan görüşmede, kavramlar arasında kurduğu ilişkilerin çerçevesini aşağıdaki gibi özetlemiştir:

Denkliği sorduğu için bana birebir-örtenliği kullanmam lazım ve onun için de fonksiyon kavramını kullanmam gerekiyor. Fonksiyonu da bir yerden başka bir yere tanımlamalıyım. Onları da tam sayılar, rasyonel sayılar gibi sayı kümelerinden seçerek kullandım.

Diğer yandan ispat süreci incelendiğinde Ç’nin bazen de eksik ya da hatalı ilişkiler kurduğu belirlenmiştir. Örneğin $\mathbb{Q}$ ve $\mathbb{Z}$ arasındaki denkliği incelerken rasyonel sayıların tanımını da dikkate alarak "f: $\mathbb{Q} \rightarrow \mathbb{Z}, \mathrm{f}(\mathrm{x})=\frac{1}{x}$ " eşlemesini oluşturmuş ve böylece tüm tam sayıların rasyonel sayılar ile eşlenebileceğini düşünmüştür. Oysaki birkaç elemanın görüntüsünü inceledikten sonra eşlemenin tanım-değer kümeleri ile birlikte değerlendirdiğinde bunun bir fonksiyon dahi olamayacağını anlamıştır. Böylece, "denklik" sezgisini doğrulayabileceği farklı örneklerin arayışına yönelmiştir. Dolayısı ile söz konusu "hatalı" ilişki Ç’nin formel ispata ulaşma sürecini uzatmasına rağmen bunu engellememiştir. Çünkü o, ilişki ağı içerisinde doğan bu tutarsızlığı belirleyebilmiş ve ispatın sonraki aşamalarına geçmeden önce onu giderebilmiştir. 


\subsubsection{B 3 - Dinamik Olma}

İspat süreci ve özellikle bu süreçte kurulan bağlantıların niteliği dikkate alındığında Ç'nin ispat sürecinin dinamik bir gelişim gösterdiği sonucuna ulaşılabilir. Özellikle o, ispat sürecinin her bir aşamasında "nedensonuç" ilişkileri bağlamında sorgulamalarda bulunmuş ve varsayımlarda bulunmaktan kaçınmıştır. Bu sayede sürecin sonraki aşamaları ile önceki aşamaları arasında tutarlı bağlantılar elde edebilmiştir. Örneğin, "denkliğe" odaklanan yaklaşımlarında yaşadığı başarısızlıkların ardından "denk olmama" durumu üzerine odaklanmaya karar vermiş ve bunun için uç örnekler kullanmayı tercih etmiştir. Bu noktada, geniş bir sayı kümesi olan gerçel sayılar $(\mathbb{R})$ kümesi ile buna göre daha küçük bir küme olduğunu düşündüğü doğal sayılar $(\mathbb{N})$ kümesini seçmiş̧ (R-) ve bunlar arasında bir eşlemenin nasıl olabileceğini hayal etmiştir. Bir süre düşündükten sonra, gerçel sayıların içerisinde yer alan irrasyonel sayıları da dikkate alarak "f: $\mathbb{N} \rightarrow \mathbb{R}, \mathrm{f}(\mathrm{x})=\sqrt{x}$ " fonksiyonunu tanımlamış ve bunu görselleştiren bir diyagramı oluşturmuştur. Tüm bu adımların sonucunda, doğal sayıların tamamını kullanmasına rağmen gerçel sayılar kümesinde açıkta elemanlar kalması gerektiğini fark etmiş ve bu kümelerin denk olamayacağına dair güçlü bir sezgiyi kazanmıştır. Sunulan bu örnekte olduğu gibi Ç’nin ispat sürecinde sonraki aşamaların önceki aşamaları içerecek şekilde basitten karmaşığa doğru tutarlı bir gelişim sağlandığı söylenebilir. Bu sayede, önceki aşamalarda bir ispat yöntemi dahi belirleyemeyen Ç’nin, aksi örnek verme yaklaşımını temel alan bir ispat yöntemini uygulamaya koyduğu gözlenmiş̧ir. Özellikle sürecin son aşamalarında doğal sayıların, irrasyonel sayılara denkliğini gösterememesi de önemli bir aşama olmuştur. Çünkü bu noktada o, bir önceki aşamada elde ettiği sonucu da dikkate alarak "doğal sayllar, irrasyonel saylara bile denk olamıyorsa gerçel sayılara denk olamaz" çıkarımına ulaşabilmiş ve aksi bir örnek elde ettiğini fark ederek kısa sürede ispatı tamamlayabilmiştir.

\subsubsection{B $_{4}$-Bütünlük}

İspat süreci bütünlük karakteristiği açısından değerlendirildiğinde Ç’nin bu karakteristiğe tam olarak sahip olduğu belirlenmiş̧tir. $\mathrm{O}$, ikinci uygulamadaki ispat sürecini ilk uygulamanın devamı olarak görmüs ve eylemlerini yeri geldikçe önceki düşünme biçimleri ile karşılaştırarak kararlar vermiştir. Bununla birlikte, Ç’nin ispat sürecinde gerek duydukça önceki aşamalar ile bağlantılar kurabildiği ve bu sayede sürece bütünsel olarak yön verebildiği de söylenebilir. Örneğin, ilk uygulamadaki olumsuz tecrübelerinin ardından ikinci uygulamanın büyük bölümünde irrasyonel sayılar üzerine düşünmekten kaçınması, onun deneyimlerden edindiği sonuçları ispata yön vermede kullandığına dair göstergeler arasında değerlendirilebilir. Diğer yandan dinamik gelişim sayesinde Ç’nin, ispat sürecini (parçalar halinde olmak yerine) tek bir bütün olarak zihninde taşıyabildiği ve yine bu sayede ispatın adımlarını detaylı olarak oluşturabildiği söylenebilir. Çünkü o, sonsuz kümelerin denk olmayacağına dair bir sezgiye ulaştığında ve doğal sayıların irrasyonel sayılar ile denkliğini gösteremediğinde (sahip olduğu bütüncül bakış sayesinde) doğal sayıların gerçel sayılara da denk anlamış ve bunu uygun temsiller altında ifade edebilmiştir. Bütüncül imajın ortaya çıkmadığı aksi bir durumda, Ç’nin farklı zamanlarda ulaştığı iki sonuç arasındaki bağlantıyı kurup ispatı tamamlamasının mümkün olamayacağı yorumu da yapılabilir. Diğger yandan, Ç’nin ispat sürecinde sorgulayıcı-formal bir yaklaşımı temel alması, gerekçelendirilmiş bir ilişki ağına ulaşması ve ispatın bileşenlerini anlamlı bir bütün olarak zihninde taşıyabilmesi sayesinde içgörü ve bunun da ötesinde bir aydınlanma deneyimleri yaşadığı sonucuna ulaşılabilir. Bunlardan ilki olan içgörü, Ç’nin denk olduğunu düşündüğü örnekleri arka arkaya sıralamasının hemen ardından ilk defa $\mathbb{Q}$ ile $\mathbb{Z}$ kümelerinin denkliğini kolayca gösteremediği aşamada şekillenmeye başlamıştır. Ancak bu kavrayış, $\mathbb{R}^{\sim} \sim \mathcal{N}$ sorusuna yanıt ararken tanımladığı "f: $\mathbb{N} \rightarrow \mathbb{R}, \mathrm{f}(\mathrm{x})=\sqrt{x}$ " fonksiyonu sayesinde kesin olarak ortaya çıkabilmiştir. Çünkü Ç, bu fonksiyonu iki küme arasında görsel bir diyagram ile ifade ettiğinde, değer kümesinde pek çok elemanın açıkla kalacağını fark etmiş ve ilk defa sonsuz kümelerin denk olamayabileceği hissetmiştir. İspat sürecinin sonunda yapılan görüşmede bu içgörüsünü aşağıdaki gibi açıklamıştır:

...bunu (kümeler arasindaki diyagram eşlemeyi göstererek) çizmek. Buraya kadar denk olabileceklerini düşünüyordum. Sayı doğrusunun çizdim ama olmadı. Ama bu kümeleri çizdiğimde boşta eleman kaldığını gördüğüm zaman (anladım)...

Diğer yandan "denk olmama” yönündeki bu ilk güçlü şüphesine rağmen söz konusu aşamada kesin bir çıkarımda bulunmaktan çekinmiş ve ispat sürecine devam etmeyi tercih etmiştir. Ancak, kısa süre sonra benzer

problemin $\mathbb{I} \stackrel{?}{\sim} \mathbb{N}$ sorusunda da tekrar ettiğini gözlemlemesi onun bir aydınlanma yaşamasını mümkün kılmıştır. Çünkü bu anda Ç, doğal sayıların irrasyonel sayılara bile denk olamadığını ve bu nedenle reel sayılara asla denk olamayacağını kavrayabilmiştir. Yaşadığı deneyimlerin, aydınlanmasına sağladığı katkıyı ispat süreci ardından yapılan görüşmede aşağıdaki gibi özetlemiş̧ir:

Denk değildir bence. Doğal sayıları verdiğimiz zaman karşısında bazı reel sayıların açıkta kaldığını gördük. Sonra irrasyonellere geldik. Aynı şekilde, doğal sayıları karşılarındaki irrasyonellere eşledik. Fakat burada açıkta kalan elemanlar oldu: “ $\sqrt{2}+2$ " gibi. Ne kadar doğal sayıyı kullanırsam kullanayım 
irrasyonel sayılarda boşluk kalacak. Bunda (irrasyonel sayıları kastediyor) eşleyemiyorsam, reel sayılarda hiç eşleyemem.

Deneyimlediği bu aydınlanma sayesinde Ç'nin ispata dair kesin bir sonuca ulaştığı, daha önce sahip olmadığ1 yeni bir bilgiyi inşa edebildiği (C-) ve ispatı kesin olarak tamamlayabildiği söylenebilir. Burada kastedilen yeni bilgi ise "birbirine denk olmayan sonsuz kümelerin de var olabileceği”" gerçeğidir.

\subsubsection{Sezgisel İkna}

Ç’nin ikinci uygulama öncesinde almış olduğu formal bilgilerin, onun bilişsel anlayışında çeşitli izler bıraktığı ve bunun da farklı duyuşsal yansımaları olduğu söylenebilir. Özellikle ilk uygulamaya kıyasla ikinci uygulamada çok daha az sayıda "varsayım" ortaya koyması bu durumun en belirgin göstergeleri arasında değerlendirilmiştir. O, ikinci uygulamada neden-sonuç ilişlerine katı bir şekilde bağlı kalmış ve bu sayede karar vermesi gereken noktalarda "sorgulayıcı" bir tavır sergileyerek ispat sürecinde ilerleyebilmiştir. Dahası, ispatın her aşamasında "ikna" olabilmeyi önemsemiş ve bu nedenle olumsuz hisler yaşadığı ve ikna olmadığı noktaları geçiştirmek yerine bunlar üzerinde derinleşmeyi tercih etmiştir. Örneğin doğal sayılar ile gerçel sayılar üzerinde uzunca düşünmesine rağmen bir sonuç alamadığında karamsar bir ifade ile aşağıdaki açıklamayı yapmıştır:

Örneklerim tükendi. (Güler) Bildiğim sonsuz kümeler tükendi. Çok basit mi düşünüyorum? Çok küçük bir parçasını mı düşünüyorum. (Sessiz kalarak düşünmeye başlar.)

$\mathrm{Bu}$ açıklama, onun deneyimlediği olumsuz hislerin bir göstergesi olarak yorumlansa da Ç, bu noktada pes etmemiş ve kümeler arasında tanımlanabilecek bijektif bir eşlemenin nasıl olabileceği üzerine odaklanmaya devam etmiştir. Bir süre sonra kurallı bir fonksiyon tanımlayamasa da görsel bir eşleme yapabileceğini fark etmiş ve bu sayede içgörü ve aydınlanma ile sonuçlanan süreci başlatmıştır. Dahası onun bu yaklaşım sayesinde sürecin pek çok noktasında olumlu hisleri (doğru iz üstünde olma, bilme, haklılık vb.) deneyimleyebildiği de görülmüştür. İspatın sonunda yapılan görüşmede doğal sayılar ile rasyonel sayıların denkliğini sorguladığı

aşamada doğru iz hissinin kesintiye uğradığını belirtse de özellikle $\mathbb{R} \stackrel{?}{\sim} \mathbb{N}$ sorusu üzerine düşünürken bu hissi tekrar güçlü bir şekilde deneyimleyebildiğini ifade etmiştir. Diğer yandan haklılık hissinin ise özellikle ispatın başlangıcında verdiği -derste önceden görmüş olduğu- örnekler için oldukça baskın olduğunu söylemiştir. Bununla birlikte, bu hissi bir süre için deneyimleyemese de his çizelgesi üzerinde aldığı notlarda "f: $\mathbb{N} \rightarrow \mathbb{R}$, $\mathrm{f}(\mathrm{x})=\sqrt{x}$ " fonksiyonu sayesinde bu hissi güçlü bir şekilde tekrar hissedebildiği belirlenmiştir. Dahası ilk defa bu eşleme sayesinde sonsuz kümelerin "denk olmaması" noktasında bir şüpheye düştüğünü de vurgulamıştır. Buna paralel olarak görüşme esnasında "kesinlik hissinin" oluşup oluşmadığ ile ilgili soruya verdiği yanıt ise aşağıda sunulmuştur:

(Tereddüt etmeden) Hissettim. Çünkü ben burada daha küçük bir küme, irrasyonel sayıları aldım. Burada sağlamıyorsa büyüttüğüm zaman reel sayılarda sağlamaz dedim.

Sunulan açıklamadan da görüldüğü gibi Ç’nin aydınlanma anına bir kesinlik hissinin eşlik ettiği söylenebilir. Çünkü o, bu aşamada kesin olarak sonsuz kümelerin denk olamayacağını anlamış ve bunu matematiksel olarak ifade edebilmiştir. Dahası bir önceki uygulamanın (Uygulama I) aksine bir sonuca ulaşabilmiş ve bu sayede ispatın tamamlandığını da söyleyebilmiştir.

\section{Tartışma, Sonuç ve Öneriler}

$\mathrm{Bu}$ çalışmada, Ç olarak isimlendirilen öğretmen adayının aynı soruya ilişkin iki farklı ispat süreci (yeterli hazırbulunuşluğa sahip olduğu ve olmadığı durumlarda) ispat imajı teorik çerçevesi bağlamında incelenmiştir. Kidron ve Dreyfus (2014) tarafindan ortaya konan ispat imaj1, hem sezgi ve hisleri içeren duyuşsal boyutun hem de içgörü ve aydınlanma anlarını içeren bilişsel aktivitelerin detaylı analizlerinde kullanılmıştır. Ç’nin Uygulama I ve Uygulama II'de yer alan ispat süreçlerinin incelenmesi sonucunda bunlar arasında bazı benzerlik ve farklılıkların olduğu tespit edilmiştir. Her iki ispat aktivitesinde de onun belirli bir amacı gerçekleştirmek için kendi kişisel anlayışı doğrultusunda girişimde bulunması, belirli matematiksel yapıları seçmesi (R-) ve bunlar arasında ilişkiler kurması (B-) en belirgin ortak noktalardandır. İspatın farklı bilgi türleri ile ilişkisi (Dreyfus, 1999) dikkate alındığında kavramlar arasında kurulan bu mantıksal bağlantıların "bilgiyi etkin kullanabilme" işlevine hizmet ettiği söylenebilir. Çünkü Barnard ve Tall (1997) tarafından da ifade edildiği gibi ispat, yeni bir bağlantı oluşturmak için çeşitli bilişsel bağların bir sentezini zorunlu kılmaktadır. Bununla birlikte, Ç’nin yeterli ön bilgiye sahip olduğu ikinci uygulamada denklik kavramı bağlamında geliştirdiği anlayışın, ilk uygulamaya kıyasla oldukça derin ve kapsamlı olduğu yorumu da yapılabilir. Özellikle bu uygulamaya dâhil ettiği örneklerin sayısındaki ve çeşitliliğindeki artışın, bakış açısındaki genişlemeden kaynaklandığı yorumu da yapılabilir. Bu sayede o, farkl1 nitelikte sorgulamalarda bulunabilmiş ve elde ettiği bulgular sayesinde ispatına yön verebilmiştir. Diğer yandan, onun yeterli formal bilgiye sahip olduğu ikinci uygulamada sezgisel varsayımları ikinci planda tutarak kavramlar arasındaki "neden-sonuç" ilişkilerini ön plana çıkardığ ve bu sayede gerekçelendirilmiş bir ilişki ağına ulaştığı da söylenebilir. Bu durum ise iki ispat sürecindeki en önemli kırılmalardan biri olan "dinamizm" karakteristiği bağlamında farklılaşmaya yol açmıştır. Oluşan 
gerekçelendirilmiş ilişki ağı sayesinde Ç’nin ikinci uygulamadaki ispat imajının, Davydov'un (1990) soyutlamaya ilişkin görüşlerine paralel olarak gelişmemiş bir formdan daha gelişmiş bir forma, basitten karmaşığa doğru bir gelişim gösterdiği belirlenmiştir. İlk uygulamada ortaya çıkan ayrık parçalar arasındaki etkileşim ve ikinci uygulamada kurulan mantıksal bağlantılar sonucunda bir senteze (C-) olanak sağlayan dinamizm aşağıdaki gibi görselleştirilebilir:

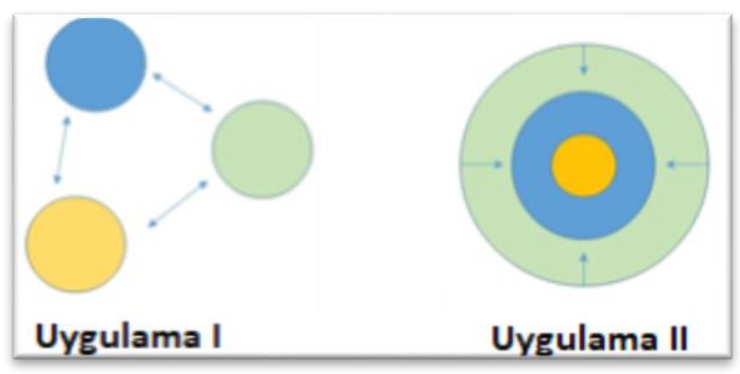

Şekil 14. Statik Yapı (Uygulama I) ve Dinamik Yapı (Uygulama II)

Bu noktada, Ç’nin ilk uygulamadaki ispat sürecinin dinamizm karakteristiğinden yoksun olması nedeni ile onun farklı örneklerden edindiği sonuçlar arasında yeterli bağlantıları kuramadığı ve bu nedenle genel bir yaklaşım şekillendirmekte zorlandığı söylenebilir. Benzer şekilde Selden, McKee ve Selden (2010) çalışmalarında bir öğrencinin ispat yapmaya çalısırıen bir sonraki adımda ne yapacağını bilemediğinde teoremle anlaşılmaz şekilde ilişkili olan şeyler yaptığını gözlemlemişlerdir. Dahası Ç'nin ikinci ispatında ortaya çıkan imajın ona iddiasının neden doğru olduğu ile ilgili içgörü sağladığı ve böylece onun sezgisel yaklaşımının da ötesine geçerek formel bir bakış elde etme ihtiyacı duyduğu söylenebilir. Söz konusu içsel motivasyon sayesinde o, tanımlar ve notasyonlar gibi formel araçları kullanarak düşüncelerini uygun bir dil ile temsil etmeye yönelmiştir. İkinci uygulamada oluşturulan görsel eşleme sonrası gerçekleştirilen süreç bu kapsamda açıklanabilir. Bu aşamada, Kidron ve Dreyfus (2014) tarafından da ifade edildiği gibi formel bilgi yapılarının (aksiyomlar, tanımlar, teoremler, ön-koşul ilişkiler vb.), daha zayıf yapıları (tekil örnekler, varsayımlar, sezgiler vb.) desteklemesi sayesinde informal boyuttan daha formal bir boyuta geçişin mümkün olduğu söylenebilir.

İki uygulama arasındaki önemli bir diğer fark da bütünlük karakteristiği olarak belirlenmiştir. Kidron ve Dreyfus'a (2014) göre imaj bütünlüğe ulaştı̆̆ında tüm matematiksel durumu eksiksiz olarak içerisinde taşır. İlk uygulamanın aksine, Ç’nin ikinci uygulamada ulaştığı bütünlük sayesinde önceki aşamalarda gerçekleştirdiği eylemleri ve sonuçlarını kesintisiz olarak zihninde taşıyabildiği ve böylece bir iç görü deneyimleyebildiği söylenebilir. Bu içgörü (ve devamında aydınlanma) ise onun ispat süreci açısından kapsamlı bir sonuca ulaşabilmesini sağlamıştır. Ayrıca, ilk uygulamada bir sonuç ortaya konamamış olması da yine bu karakteristiğin eksikliği bağlamında değerlendirilmiştir. Bunlara ek olarak his boyutu incelendiğinde, Ç’nin ikinci uygulamada ispatlama eylemlerine yön veren aşina olma hissi, bilme hissi, haklılık hissi ve kesinlik hissi gibi temel hisleri çeşitli noktalarda zincirleme olarak deneyimleyebildiği ve sonunda ispatın bütünü için bir tamamlanmışlık hissine ulaşabildiği görülmüştür. Ancak, ilk uygulamada bilişsel eylemlerinde yaşadığı güçlüklere paralel olarak bazı olumlu hisleri sadece anlık olarak deneyimleyebildiği ve kesinlik hissine ulaşamadığ

Sunulan bu çalışmanın içerdiği özel örnekler göz önüne alındığında formal bilginin, ispat imajının oluşumuna sunduğu temel katkılar aşağıdaki maddeler halinde özetlenebilir:

- İddianın neden doğru olduğuna ilişkin sezgisel bir anlayış geliştirilmesi,

- Özgün bir ispat yaklaşımı belirlenmesi,

- Düşünceleri destekleyebilecek argümanların sunulması,

- İspat aşamaları arasındaki geçişlerde (varsayımlar yerine) gerekçelendirilmiş ilişkilerin dikkate alınması,

- İspat sürecinin tutarsız bir formdan tutarlı bir forma doğru süreç olarak ilerlemesi,

- İspatın basitten karmaşığa bir geliş̧im göstermesi,

- İçgörü ve/veya aydınlanma deneyimlerinin gerçekleşebilmesi,

- Doğru temsiller ile ispat adımlarının detaylı olarak oluşturulması,

- Olumlu hislerin (doğru iz üstünde olma, bilme, haklılık, kesinlik vb.) deneyimlenebilmesi,

- Tamamlanmışlık hissinin ortaya çıkması,

- İspatın sonuçlandırılması.

Yukarıda sunulan maddelerin tamamının, imajın bileșenleri ile doğrudan ilişkili olduğu söylenebilir. Bu sonuçlardan hareketle bir öğretim elemanı tarafindan gerçekleştirilen ispat uygulamalarında öğretmen adaylarının ispat imajlarını tetikleyebilecek bazı öneriler aşağıda sıralanmıştır:

$\checkmark$ Kavramsal altyapı tam ve eksiksiz olarak oluşturulmalıdır.

$\checkmark$ İspat yöntemleri açıklanmalı ve bunların kullanım biçimleri örnekler üzerinde gösterilmelidir. 
$\checkmark \quad$ Farklı temsil biçimlerinden hareketle dinamik düşünme biçimleri teşvik edilmelidir.

$\checkmark$ Varsayım ile delil arasındaki fark vurgulanmalıdır.

$\checkmark$ İspatın temel taşlarından biri olan "gerekçelendirme" boyutu açıklanmalı ve ispat adımları arasındaki geçişlerde tutarlılığı sorgulama alışkanlığı kazandırılmalıdır.

$\checkmark \quad$ İspat olan ve olmayan durumlar arasındaki fark vurgulanmalıdır.

$\checkmark$ Hislerin/ sezgilerin sorgulanabilirliği sıkça hatırlatılmalıdır.

Sunulan önerilere ek olarak, bireylere formal bilginin sunulmasının, ispat imajının oluşumu açısından bir kesinlik sağlayacağı da söylenemez. Bu çalışmanın da bir bölümünü oluşturduğu doktora tez çalışması kapsamında yapılan bazı uygulamalarda katılımcıların formal bilgiye sahip oldukları halde bir ispat imajına sahip olmadıklarına dair örneklere rastlanılmıştır. Bu çalışmada ispat imajının ortaya çıktığı durumlara odaklanıldığından söz konusu bulgulara yer verilmemiştir. Bununla birlikte, sunulan çalışmada Ç’nin ikinci uygulamada bir ispat imajına sahip olmasına rağmen formal ispata ulaşamadığı da görülmüştür. O, ispat sürecinin özellikle son aşamalarında doğal sayılar ile gerçel sayılar arasındaki ilişkiye odaklanmış ve bu iki kümenin denk olmadığına karar vermiştir. Ancak onun bu yaklaşımı iki küme arasında tanımlanacak hiçbir eşlemenin bijektif olamayacağının formal bir genelleştirmesini içermediğinden formal ispat olarak değerlendirilmemişidir. Matematik tarihi açısından büyük bir kırılmaya yol açan bu ispat ilk olarak Cantor (1891) tarafından köşegensel (diagonal) bir eşleme kullanılarak oluşturulmuştur. Ç’nin ispatında "sonsuzluk" kavramını Cantor tarafından önerilen anlamı ile bijektif fonksiyonlar çerçevesinde kullandığı dikkate alındığında onun sadece ispata dair bir doğrulama yaptığı sonucuna ulaşılabilir. Dolayısı ile bireylerin "bir ispat imajına sahip oldukları halde formal ispata nasıl ulaşabilecekleri” sorusu halen detaylandırılmayı beklemektedir. Ayrıca, Kidron ve Dreyfus (2014) tarafından önerildiği gibi ispat imajının farklı yaş gruplarında ve farklı konu alanları kapsamında incelenmesi ile ispat kavramının doğasına ilişkin anlayış derinleştirilebilir.

\section{Etik Kurul Onay Bilgileri}

Araştırma ile ilgili Dokuz Eylül Üniversitesi, Eğitim Bilimleri Etik Kurulu'ndan 18/04/2019 tarih ve 2019/04 protokol numarası ile etik kurul uygunluk onayı alınmıştır.

\section{Kaynaklar / References}

Almeida, D. (2000). A survey of mathematics undergraduates' interaction with proof: Some implications for mathematics education. International Journal of Mathematical Education in Science and Technology, 31(6), 896-890.

Altun, M. (2005). Matematik ögretimi. Bursa: Aktüel Yayınevi.

Antonini, S. \& Mariotti, M. A. (2007). Indirect proof: An interpreting model. In D. Pitta-Pantazi, \& G. Philippou (Eds.), Proceedings of the $5^{\text {th }}$ Congress of the European Society for Research in Mathematics Education (pp. 541-550). Cyprus: Larnaca.

Atwood, P. R. (2001). Learning to construct proofs in a first course on mathematical proof (Unpublished doctoral dissertation). Western Michigan University, USA.

Baker, D., \& Campbell, C. (2004). Fostering the development of mathematical thinking: Observations from a proofs course. Problems, Resources, and Issues in Mathematics Undergraduate Studies, 14(4), 345-353.

Barnard, A. D. \& Tall, D. O. (1997). Cognitive Units, Connections, and Mathematical Proof. In E. Pehkonen, (Ed.), Proceedings of the $21^{\text {st }}$ Annual Conference for the Psychology of Mathematics Education, Vol. 2 (pp. 41-48). Lahti, Finland.

Bikner-Ahsbahs, A. (2004). Towards The Emergence of Constructing Mathematical Meanings. In M. J. Hoines and A. B. Fuglestad (Eds.), Proceedings of the $28^{\text {th }}$ Conference of the International Group for the Pychology of Mathematics Education, Vol. 2 (pp. 119-126). Bergen, Norway.

Büyüköztürk, Ş., Kılıç Çakmak, E., Akgün, Ö. E., Karadeniz, Ş. ve Demirel, F. (2013). Bilimsel araştırma yöntemleri. Ankara: Pegem Akademi Yayınevi.

Clore, G. L. (1992). Cognitive phenomenology: Feelings and the construction of judgment. In L. L. Martin, \& A. Tesser (Eds.), The construction of social judgments (pp. 133-163). Hillsdale, NJ: Erlbaum.

Davydov, V. V. (1990). Types of Generalization in Instruction: Logical and Psychological Problems in the Structuring of School Curricula. In J. Kilpatrick (Ed.) and J. Teller (Trans.), Soviet Studies in Mathematics Education: Volume 2. Reston, VA: NCTM. (Original work published 1972).

Doruk, M. ve Kaplan, A. (2017). İlköğretim matematik öğretmeni adaylarının analiz alanında yaptıkları ispatların özellikleri. Mehmet Akif Ersoy Üniversitesi Eğitim Fakültesi Dergisi, 44, 467-498.

Dreyfus, T. (1999). Why Johnny can't prove. Educational Studies in Mathematics, 38(1), 85-109.

Fischbein, E. (1982). Intuition and proof. For the Learning of Mathematics, 3(2), 9-24. 
Fischbein, E. (1994). The interaction between the formal, the algorithmic and the intuitive components in a mathematical activity. In R. Biehler, R. W. Scholz, R. Sträßer \& B. Winkelmann (Eds.), Didactics of mathematics as a scientific discipline (pp. 231 245). Dordrecht, The Netherlands: Kluwer.

Cantor, G. (1891). "Ueber eine elementare frage der mannigfaltigkeitslehre". Jahresbericht der Deutschen Mathematiker-Vereinigung, 1, 75-78.

Güler, G. \& Dikici, R. (2014). Examining prospective mathematics teachers' proof processes for algebraic concepts. International Journal of Mathematical Education in Science and Technology, 45(4), 475-497.

Güler, G., Özdemir, E. ve Dikici, R. (2012). Öğretmen adaylarının matematiksel tümevarım yoluyla ispat becerileri ve matematiksel ispat hakkındaki görüşleri. Kastamonu Ĕ̌itim Dergisi, 20(1), 219-236.

Güney, Z. ve Özkoç, M. (2015). Soyut Matematik. İzmir: Dinozor Kitabevi.

Hanna, G. (2000). Proof, explanation and exploration: An overview. Educational Studies in Mathematics, 44, 523.

Harel, G., \& Sowder, L. (1998). Students' proof schemes: Results from exploratory studies. Research in Collegiate Mathematics Education, 3(7), 234-282.

Harel, G. \& Sowder, L. (2007). Toward comprehensive perspectives on the learning and teaching of proof. In F. K. Lester, Jr. (Ed.), Second handbook of research on mathematics teaching and learning (pp. 805-842). Greenwich, CT: Information Age.

Hart, E. W. (1994). A conceptual analysis of the proof-writing performance of expert and novice students in elementary group theory. In J. J. Kaput \& E. Dubinsky (Eds.), Research Issues in Undergraduate Mathematics Learning: Preliminary Analyses and Results (pp.49-62.), Washington, DC: Mathematical Association of America.

Herbst, P. (2002). Engaging students in proving: A double bind on the teacher. Journal for Research in Mathematics Education, 33(3), 176-203.

Hershkowitz, R., Schwarz, B. B. \& Dreyfus, T. (2001). Abstraction in context: Epistemic actions. Journal for Research in Mathematics Education, 32(2), 195-222.

Jones, K. (2000). The student experience of mathematical proof at university level. International Journal of Mathematical Education in Science and Technology, 31(1), 53-60.

Kaptan, S. (1998). Bilimsel araştırma ve istatistik teknikleri. Ankara: Tekışık Web Ofset.

Kidron, I. \& Dreyfus, T. (2009). Justification, enlightenment and the explanatory nature of proof. In F.-L. Lin, F.-J. Hsieh, G. Hanna \& M. de Villiers (Eds.), Proceedings of the ICMI Study 19 Conference: Proof and Proving in Mathematics Education, Vol. 1 (pp. 244-249). Taipei, Taiwan.

Kidron, I. \& Dreyfus, T. (2010). Justification enlightenment and combining constructions of knowledge. Educational Studies in Mathematics, 74(1), 75-93.

Kidron, I. \& Dreyfus, T. (2014). Proof image. Educational Studies in Mathematics, 87(3), 297-321.

Knapp, J. (2005). Learning to prove in order to prove to learn. Retrieved February 29, 2020 from https://mathpost.asu.edu/ sjgm/issues/2005_spring/SJGM_knapp.pdf.

Knuth, E. J. (2002). Teachers' conceptions of proof in the context of secondary school mathematics. Journal of Mathematics Teachers Education, 5, 61-88.

Ko, Y. Y. \& Knuth, E. (2009). Undergraduate mathematics majors' writing performance producing proofs and counterexamples about continuous functions. The Journal of Mathematical Behavior, 28(1), 68-77.

Kolar, V. M. \& Čadež, T. H. (2012). Analysis of factors influencing the understanding of the concept of infinity. Educational Studies in Mathematics, 80(3), 389-412.

Liljedahl, P. G. (2004). the AHA! Experience: Mathematical contexts, pedagogical implications (Unpublished doctoral dissertation). Simon Fraser University, Canada.

Liljedahl, P. G. (2005). Mathematical discovery and affect: The effect of AHA! experiences on undergraduate mathematics students. International Journal of Mathematical Education in Science and Technology, 36(3), 219-234.

Moore, R. C. (1994). Making the transition to formal proof. Educational Studies in Mathematics, 27(3), 249266.

Pala, O., \& Narl1, S. (2018b). Examining proof schemes of prospective mathematics teachers towards countability concept. Necatibey Faculty of Education Electronic Journal of Science \& Mathematics Education, 12(2), 136-166.

Pala, O. ve Narlı, S. (2018a). Matematik öğretmeni adaylarının sonsuz kümelerin denkliği ile ilgili ispatlama yaklaşımları ve yaşadıkları güçlükler. Turkish Journal of Computer and Mathematics Education, 9(3), 449475.

Rota, G. C. (1997). Indiscrete thoughts. Boston, MA: Birkhäuser.

Sandefur, J., Mason, J., Stylianides, G. J. \& Watson, A. (2013). Generating and using examples in the proving process. Educational Studies in Mathematics, 83(3), 323-340. 
Sarı, M., Altun, A. ve Aşkar, P. (2007). Üniversite öğrencilerinin analiz dersi kapsamında matematiksel kanıtlama süreçleri: Örnek olay çalışması. Ankara Üniversitesi Ĕ̆itim Bilimleri Fakültesi Dergisi, 40(2), 295-319.

Schoenfeld, A. H. (1994). What do we know about mathematics curricula?. The Journal of Mathematical Behavior, 13(1), 55-80.

Schwarz, B., Dreyfus, T., Hadas, N., \& Hershkowitz, R. (2004). Teacher guidance of knowledge construction. In M. J. Hoines, \& A.B. Fuglesad (Eds.), Proceedings of the $28^{\text {th }}$ conference of the international group for the psychology of mathematics education (pp. 169-176). Bergen, Norway.

Selden, A., McKee, K., \& Selden, J. (2010). Affect, behavioural schemas and the proving process. International Journal of Mathematical Education in Science and Technology, 41(2), 199-215.

Selden, J. \& Selden, A. (1995). Unpacking the logic of mathematical statements. Educational Studies in Mathematics, 29(2), 123-151.

Selden, A., \& Selden, J. (2007). Overcoming students'difficulties in learning to understand and construct proofs (Technical Report No: 2007-1). Cookeville, TN: Tennesse Technological University, Department of Mathematics. Retrieved February 21, 2020 from http://www.math.tntech.edu/techreports/TR_2007_1.pdf

Sönmez, V. ve Alacapınar, F. G. (2011). Örneklendirilmiş bilimsel araştırma yöntemleri. Ankara: Anı Yayıncilik.

Stylianides, A. J. (2007). Proof and proving in school mathematics. Journal for Research in Mathematics Education, 38(1), 289-321.

Tall, D. (1998, August). The cognitive development of proof: Is mathematical proof for all or for some. Paper presented at Conference of the University of Chicago School Mathematics Project, Chicago.

Tall, D. \& Vinner, S. (1981). Concept image and concept definition in mathematics with particular reference to limits and continuity. Educational Studies in Mathematics, 12(2), 151-169.

Thompson, D. R., Senk, S. L. \& Johnson, G. J. (2012). Opportunities to learn reasoning and proof in high school mathematics textbooks. Journal for Research in Mathematics Education, 43(3), 253-295.

Tsamir, P. (1999). The transition from comparison of finite to the comparison of infinite sets: Teaching prospective teachers. Educational Studies in Mathematics, 38, 209- 234.

Türnüklü, E. ve Özcan, B. (2014). Öğrencilerin geometride RBC teorisine göre bilgiyi oluşturma süreçleri ile Van Hiele geometrik düşünme düzeyleri arasındaki ilişki: Örnek olay çalışması. Mustafa Kemal Üniversitesi Sosyal Bilimler Enstitüsü Dergisi, 11(27), 295-316.

Weber, K. \& Alcock, L. (2004). Semantic and syntactic proof productions. Educational Studies in Mathematics, 56(3), 209-234.

Weber, K. \& Alcock, L. (2009). Proof in advanced mathematics classes. In D. A. Stylianou, M. L. Blanton \& E. J. Knuth (Eds.), Teaching and learning across the grades: A K-16 perspective (pp. 323-338). New York, NY: Routledge.

Weber, K. (2001). Student difficulty in constructing proofs: The need for strategic knowledge. Educational Studies in Mathematics, 48, 101-119.

Weber, K. (2006). Investigating and teaching the processes used to construct proofs. In F. Hitt, G. Harel \& S. Hauk (Eds.), Research in college mathematics education, VI (pp. 197-232). RI: American Mathematical Society.

Yıldırım A. ve Şimşek H. (2013). Sosyal bilimlerde nitel araştırma yöntemleri. Ankara: Seçkin Yayıncılık. 